\title{
Seasonal variability of meiofauna, especially harpacticoid copepods, in Posidonia oceanica macrophytodetritus accumulations
}

\author{
Thibaud Mascart $^{\mathrm{a}, \mathrm{b}, *}$, Gilles Lepoint ${ }^{\mathrm{b}}$, Silke Deschoemaeker ${ }^{\mathrm{a}}$, Marc Binard ${ }^{\mathrm{c}}$, \\ François Remy ${ }^{\mathrm{b}}$, Marleen De Troch ${ }^{\mathrm{a}}$ \\ a Marine Biology, Ghent University, Krijgslaan 281-S8, B-9000 Gent, Belgium \\ ${ }^{\mathrm{b}}$ MARE Centre, Laboratory of Oceanology, University of Liège, Allée du 6 août -B6c, B-4000 Liège, Belgium \\ ${ }^{c}$ MARE Centre, Geomatic Unit, University of Liège, Allée du 6 août -B5a, B-4000 Liège, Belgium
}

\section{A R T I C L E I N F O}

\section{Article history:}

Received 12 February 2014

Received in revised form 20 June 2014

Accepted 14 July 2014

Available online 25 July 2014

\section{Keywords:}

Leaf litter accumulations

Posidonia oceanica

Macrophytodetritus

Seasonal distribution

Meiofauna

Harpacticoida

\begin{abstract}
A B S T R A C T
The overall aim of this study was (1) to assess the diversity and density of meiofauna taxa, especially harpacticoid copepod species, present within accumulated seagrass macrophytodetritus on unvegetated sand patches and (2) to elucidate the community structure of detritus-associated harpacticoid copepods in relation to natural temporal variability of physico-chemical characteristics of accumulations. This was investigated in a Posidonia oceanica (L.) Delile seagrass ecosystem in the northwest Mediterranean Sea (Bay of Calvi, Corsica, 42 $2^{\circ} 35^{\prime} \mathrm{N}$, $8^{\circ} 43^{\prime} \mathrm{E}$ ) using a triplicate macrophytodetritus core field sampling in two contrasting sites over the four seasons of 2011. Meiofauna higher taxa consisted of $50 \%$ Copepoda, of which $87 \%$ belonged to the Harpacticoida order. Nematoda was the second most abundant taxa. The copepod community displayed a wide variety of morphologically similar and ecologically different species (i.e. mesopsammic, phytal, phytal-swimmers, planktonic and parasitic). The harpacticoid copepod community followed a strong seasonal pattern with highest abundances and species diversity in May-August, revealing a link with the leaf litter epiphyte primary production cycle. Aside from the important role in sheltering, housing and feeding potential of macrophytodetritus, a harpacticoid community BEST analysis demonstrated a positive correlation with habitat complexity and a negative correlation with water movements and $P$. oceanica leaf litter accumulation.
\end{abstract}

(C) 2014 Elsevier B.V. All rights reserved.

\section{Contents}

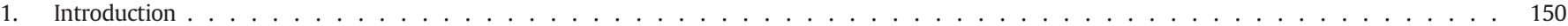

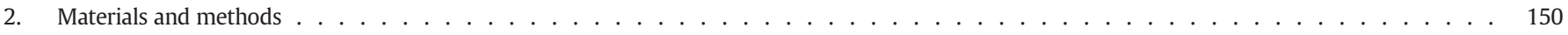

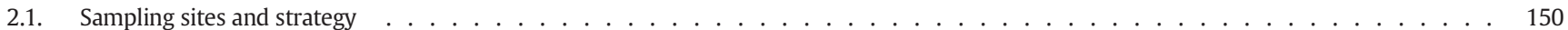

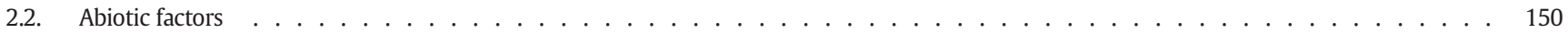

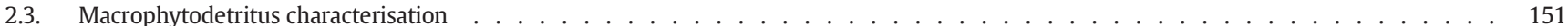

2.4. Meiofauna community characterisation . . . . . . . . . . . . . . . . . . . . . . . . 151

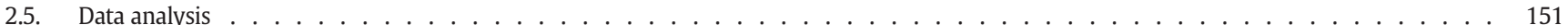

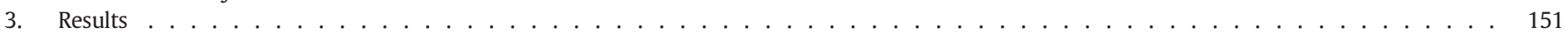

3.1. Environmental data: macrophytodetritus characterisation . . . . . . . . . . . . . . . . . . . . . . . . 151

3.2. Environmental data: abiotic factors . . . . . . . . . . . . . . . . . . . . . . . . . . . . . . . . 152

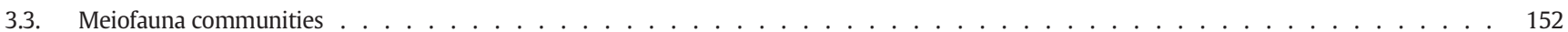

3.4. Harpacticoid copepod species composition . . . . . . . . . . . . . . . . . . . . . . . . . . . . 153

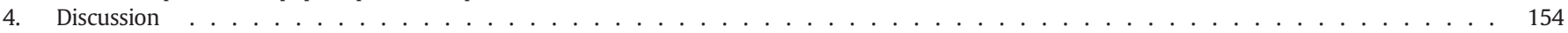

4.1. Harpacticoid copepod species assemblage in detritus . . . . . . . . . . . . . . . . . . . . . . . . . . . . . . . . 154

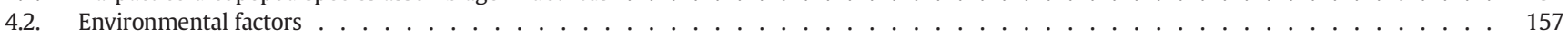

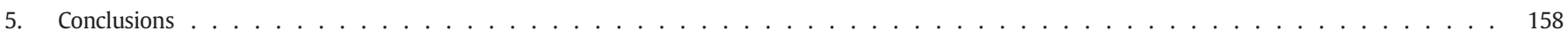

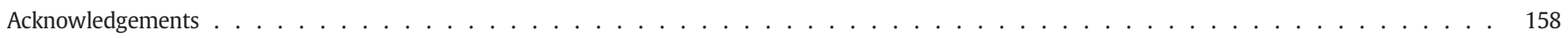

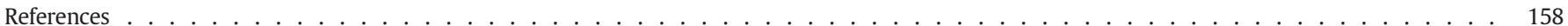

* Corresponding author. Marine Biology, Ghent University, Krijgslaan 281-S8, B-9000 Gent, Belgium.

E-mail address: thibaud.mascart@ugent.be (T. Mascart). 


\section{Introduction}

In the Mediterranean Sea, seagrass meadows of Posidonia oceanica (L.) Delile cover vast areas of sea bottom. Yearly at the end of summer, the seagrass losses a major part of its leaf biomass after senescence. The fate of these $P$. oceanica dead leaves, also called leaf litter, varies (Pergent et al., 1997): a part of the leaf litter decays slowly or is buried within the meadow, while another part is exported to other adjacent habitats where it may represent a considerable organic material input (Cebrian et al., 1997; Duarte and Cebrian, 1996; Pergent et al., 1994; Romero et al., 1994). Such exported leaf litter mixes with drift epilithic macroalgae, uprooted living seagrass shoots with rhizomes, other seagrass litter, seeds, dead macrofauna and fine sediment to form detritus. The exported detritus form dense accumulations, especially on adjacent unvegetated sand patches, in relation to local hydrodynamics and sand patch morphology (Vetter and Dayton, 1999). The macrophytodetritus host many organisms which can participate in the degradation of this organic material, such as bacteria, fungi, diatom microalgae and invertebrates (Danovaro, 1996; Danovaro et al., 2002; Gallmetzer et al., 2005; Graca, 2001; Mancinelli and Rossi, 2002). Especially motile macro- (>1 mm) and meiofauna (38 $\mu \mathrm{m}-$ $1 \mathrm{~mm}$ ) invertebrates were revealed to be important in the shredding, degrading and decomposing of the organic wrack (Hyndes and Lavery, 2005; Lillebo et al., 2007; Mancinelli and Rossi, 2002; Vetter, 1995; Wittman et al., 1981).

Several studies in coastal ecosystems compared motile invertebrate communities in living seagrass habitats with communities present in directly adjacent habitats (unvegetated sand, root-rhizome matte and macrophytodetritus accumulations). Unvegetated sand showed a lower abundance of associated motile macro- and meiofauna than the foliar substrata of living seagrasses (Bostrom and Bonsdorff, 1997; Connolly, 1997; Edgar et al., 1994; Fonseca et al., 2011; Sanchez-Jerez et al., 1999). In the P. oceanica ecosystem, the root-rhizome layer mat supports diverse macro-invertebrate assemblages (Harmelin, 1964). These mats occur with live rhizomes or naturally dead rhizomes. The comparison between the dead and the living habitat yielded a higher total number of species and abundance in the dead detrital mat (Borg et al., 2006). However, certain randomness in the species assemblages was present depending on subliminal parameters such as the substrate compactness, bacterial growth, and depth (Abada Guerroui and Willise, 1984; Harmelin, 1964). Macrofaunal communities in macrophytodetritus accumulations on unvegetated sand patches were, in terms of diversity low, but in terms of total abundance equal to or higher than living seagrasses (Como et al., 2008; Dimech et al., 2006; Gallmetzer et al., 2005; Mancinelli and Rossi, 2002). Consequently, dead habitats and especially macrophytodetritus accumulations seem to support a unique macro-invertebrate assemblage.

Meiofauna are said to play an important role in the degradation of leaf litter (Hyndes and Lavery, 2005; Lillebo et al., 2007). In some habitats, studies were made and clear associations between detritus and meiofauna assemblages were established, such as in mangrove leaf litter (Gee and Somerfield, 1997; Gwyther, 2003; Torres-Pratts and Schizas, 2007) or in terrestrial forest (Dumont and Maas, 1988; Fiers and Ghenne, 2000). In seagrass ecosystems, food webs are mainly seen as detrital (Duarte and Cebrian, 1996; Mateo and Romero, 1997; Pergent et al., 1994), but many potential food sources coexist (Lepoint et al., 2000). No study, to our current knowledge, was ever performed on the harpacticoid copepod assemblage associated with seagrass macrophytodetritus. Mascart et al. (2013) compared $P$. oceanica meadows, sediment and two types of macrophytodetritus accumulations. The macrophytodetritus accumulations showed higher meiofauna abundances than living seagrasses, without expressing a higher diversity. Consequently, do macrophytodetritus accumulations support a unique meiofauna community, in particular harpacticoid copepods and what is the origin and variability of this community?
The overall aim of this study was to assess the diversity and density of meiofauna taxa, especially harpacticoid copepod species, present within macrophytodetritus wrack accumulations on unvegetated sand patches. A second aim was to elucidate the community structure of associated meiofauna and harpacticoid copepods to natural temporal variability of physico-chemical characteristics of macrophytodetritus accumulations. We investigated this by collecting triplicate macrophytodetritus core samples in the four seasons of the year in two contrasting sites. We addressed the following specific questions: (1) Do wind gusts act as a proxy for near bottom currents that control the dynamics of the macrophytodetritus? (2) Does the temporal dynamics have an effect on the meiofauna and copepod community composition and density in two contrasting sites? (3) What are the ecological groups of copepods present in the litter accumulation (i.e. planktonic, phytal or mesopsammic)?

\section{Materials and methods}

\subsection{Sampling sites and strategy}

Samples were collected in the Revellata Bay in the Gulf of Calvi, Corsica, northwest Mediterranean $\left(42^{\circ} 35^{\prime} \mathrm{N}, 8^{\circ} 43^{\prime} \mathrm{E}\right)$. At the study site, P. oceanica seagrass meadows cover about $50 \%$ of the total bay surface down to a depth of $38 \mathrm{~m}$ (Bay, 1984) and are ranked amongst the most productive $P$. oceanica beds in the north west Mediterranean (Pergent-Martini et al., 1994). Annual surface temperatures have a classical summer maximum $\left(26^{\circ} \mathrm{C}\right.$ in August) and winter minimum $\left(13{ }^{\circ} \mathrm{C}\right.$ in March). Currents are weak $\left(\leq 5 \mathrm{~cm} \cdot \mathrm{s}^{-1}\right)$ and the salinity is 38 and stable throughout the year. The dominant winds on the Bay originate from the South-West (Libeccio, 200-250 ${ }^{\circ}$ ) and North (Mistral and Tramontane, $320-60^{\circ}$ ) sectors (Bay, 1984; Dauby et al., 1995).

Samples were taken seasonally, i.e. in the months of February, May, August and October of 2011 representing winter, spring, summer and autumn, respectively. Sampling was carried out at a depth of $10 \mathrm{~m}$ by scuba divers during day time and calm sea conditions. Two contrasting sampling sites at about $1 \mathrm{~km}$ from each other were selected. Both sampling sites offered sandy patches with different local hydrodynamic conditions and variable shapes and patch sizes. The first sampling site was located in front of the harbour of the STARESO research facility and was referred to as PORT. The second sampling site was situated in front of the Punta Oscellucia peninsula and was referred to as OSCE. In each site, triplicate PVC cores were randomly pushed into the macrophytodetritus accumulation (inner diameter $=20 \mathrm{~cm}$, surface $=0.0314 \mathrm{~m}^{2}$ ). All detritus contained in the tube was gently scooped off the seafloor bed by hand and put into $6 \mathrm{~L}$ sealed plastic jars. Sediment was not taken. In order to ensure no loss of material or contamination, all jars were closed under water. In order to separate meiofauna from the macrophytodetritus, an $8 \% \mathrm{MgCl}_{2}$-solution was added (Hulings and Gray, 1971) and fresh water rinsing was used to stun the organisms. The samples were rinsed twice over a $1 \mathrm{~mm}$ mesh sieve to exclude detritus. Meiofauna was retained on a $38 \mu \mathrm{m}$ mesh sieve and preserved in a $4 \%$ formaldehyde seawater solution. The defaunated detritus was stored frozen $\left(-18{ }^{\circ} \mathrm{C}\right)$.

\subsection{Abiotic factors}

Meteorological data were recorded during the entire year in order to map the effect of the weather on the local hydrodynamics. Previous studies stated that currents in the study site are weak $\left(\leq 5 \mathrm{~cm} \cdot \mathrm{s}^{-1}\right)$ and circulation mainly consists of a local residual gyre (Dauby et al., 1995). According to ocean surface mixed layer models (see CushmanRoisin and Beckers, 2011 and references therein) it is generally accepted that the surface winds, next to other factors like off-shore generated swell, have a direct influence on the bottom currents. Shallow regions (typically with a depth of $10 \mathrm{~m}$ ) are considered to be dominated by shear turbulence and friction (Cushman-Roisin and Beckers, 2011). 
Therefore the surface wind can be used as proxy for the near bottom currents. For the purpose of this study, only wind gusts, i.e. maximum wind speed over a two-second period at any time during $20 \mathrm{~min}$, higher than $3.06 \mathrm{~m} \cdot \mathrm{s}^{-1}$ were taken into account. Due to the geographical location and orientation of the bay, east-southerly to westerly winds are sheltered and thus have almost no effect on the local sea surface of the sampling sites. Therefore only wind gusts blowing from the $1 \mathrm{st}$ quadrant $\left(0-90^{\circ}\right)$, coming from North to East, were selected. In order to characterise and relate the selected wind gusts, two factors were included in the analysis: (1) wind gust velocity, i.e. the median speed of the wind gusts during the time frame and (2) wind gust quantity, i.e. the percentage of time gusts blowing during the time frame. The selected timeframe relevant to the sampling scale was four weeks prior to sampling, to map the long-term effects of the wind.

For each sample collection site at each season $(N=24)$, water was sampled using a $60 \mathrm{ml}$ direct-suction filter sampler from Gobert et al. (2006) at different positions: the water column (WC), the water just above the detritus (WJA), the water inside the detritus (WI) and the interstitial water of the underlying sediments (IW). Nutrient concentrations, nitrogen $\left(\mathrm{NH}_{4}^{+}\right.$and $\mathrm{NO}_{3}+\mathrm{NO}_{2}$, hereafter $\left.\mathrm{NO}_{\mathrm{x}}\right)$ and phosphate $\left(\mathrm{HPO}_{4}^{2-}\right.$ ) were analysed with an autoanalyser (SKALAR San + continuous flow analyser) based on the method of Grasshoff et al. (2007) adapted for oligotrophic (low nutrient content) seawater (detection limits: 0.1, 0.04 and $0.05 \mu \mathrm{M}$ for ammonium, NOx and phosphates, respectively). Oxygen concentrations were measured using the Winkler method with $13 \mathrm{ml}$ biological oxygen demand (BOD) bottles. The Winkler method titration of iodine with a thiosulfate solution was adapted for microvolumes (Strickland and Parsons, 1968). Oxygen concentration was not measured in interstitial water of the underlying sediments. Oxygen values under $63 \mu \mathrm{M}$ were defined as hypoxic (Middelburg and Levin, 2009).

\subsection{Macrophytodetritus characterisation}

During sampling, the macrophytodetritus accumulation height (Detritus height) was measured with a ruler stick pushed through the detritus alongside the core. The detritus accumulation was constituted of heterogeneous material, therefore after thawing, the defaunated macrophytodetritus was sorted in three categories: (1) the dead $P$. oceanica leaf litter fragments, (2) the drift epilithic macroalgae (Drift macroalgae) and (3) the living shoots of $P$. oceanica comprising rhizomes and living leaves (Living $P$. oceanica). In order to display the different contributions, all categories were dried at $60{ }^{\circ} \mathrm{C}$ for $96 \mathrm{~h}$. Prior to dry weighting of the leaf litter category, the 25 first fragments were scraped according to Dauby and Poulicek (1995) to remove the epiphytes which would bias the weight of the leaf litter fragments. Afterwards, for calculation purposes, the total epiphyte dry weight (Leaf litter epiphytes DW) and net leaf litter dry weight (Leaf litter DW) were extrapolated from the measurements of the first 25 fragments. Standardisation of dry weight was done towards $\mathrm{gDW} \cdot \mathrm{m}^{-2}$ extrapolated from the core surface. An extra detritus characterisation factor (Epi/ Lit ratio) was mathematically added for the BEST analysis (see further). The leaf litter epiphytes DW/leaf litter DW ratio was created (Epi/Lit ratio), since the seasonal fluctuation of the epiphytic primary production (read: leaf litter epiphytes DW) and the P. oceanica leaf senescence (read: leaf litter DW) don't follow the same pattern.

\subsection{Meiofauna community characterisation}

In the lab, the $38 \mu \mathrm{m}-1 \mathrm{~mm}$ fraction of each replicate was centrifuged three times with Ludox HS40 (specific density of $1.18 \mathrm{~g} \cdot \mathrm{dm}^{-3}$ ) in order to extract meiofauna from the macrophytodetritus derived organic material. Meiofauna was stained with Rose Bengal before being sorted and enumerated at a higher taxon level based on Higgins and Thiel (1988). Harpacticoid copepods were picked out and stored in $75 \%$ ethanol. Due to time-consuming identification we restricted ourselves to the first one hundred twenty adult harpacticoid copepods (De Troch et al., 2001), representing 15 to $95 \%$ of the total adult copepod amount. Copepods were mounted in toto on glycerine slides for identification at species level using the identification keys and reference books by Boxshall and Hasley (2004) and Lang $(1948,1965)$. The number of individuals was standardised by area $\mathrm{m}^{2}$ and towards dry weight $\mathrm{g}$ extrapolated from the core surface and leaf litter dry weight, respectively.

\subsection{Data analysis}

A fully crossed 2-factor design was performed in PERMANOVA with fixed factors month and site for the multivariate harpacticoid copepod species composition and univariate diversity indices and environmental variables (excluding nutrients and oxygen). A fully crossed 3-factor design was performed in PERMANOVA with fixed factors month, site and position for the environmental variables nutrients and oxygen. A BrayCurtis and Euclidean distance based resemblance matrix was used for untransformed multivariate and normalised univariate measures, respectively. Significant differences between groups can be shown by PERMANOVA, but no difference due to location (factor effect) or due to dispersion (variance) can be distinguished. Therefore, homogeneity of dispersion was tested with a PERMDISP, using distances amongst centroids calculated on the lowest level (Quinn and Keough, 2002). For univariate Euclidian distance the PERMDISP test is equivalent to the traditional univariate Levene's test (Anderson et al., 2008). Posthoc comparisons were performed using Pair-wise tests type III. Copepoda species diversity was measured as species richness and Hill's diversity indices (Hill, 1973): $\mathrm{S}=$ number of different species; $\mathrm{N}_{1}=$ $\exp \left(\mathrm{H}^{\prime}\right)$, where $\mathrm{H}^{\prime}$ is the Shannon-Wiener diversity index based on the natural logarithm $(\ln ) ; N_{2}=1 / \lambda$, where $\lambda$ is Simpson's index.

Within the multivariate analysis, a SIMPER (similarity percentages) analysis was done to identify the main harpacticoid copepod species primarily providing the discrimination between the groups. A principal coordinate analysis (PCO) based on a Bray-Curtis similarity resemblance matrix of untransformed relative data of meiofauna taxa or harpacticoid copepod species was performed to visualise the community structure amongst the different months and sites (Anderson et al., 2008). In order to find the best explanatory environmental variable for the meiofauna and harpacticoid copepod community structure, a multivariate BEST analysis with the BIOENV algorithm based on the Spearman rank correlation coefficient was performed (Clarke and Gorley, 2006). The same BEST analysis was performed on the univariate data of the five most dominant harpacticoid copepods, representing each more than $5 \%$ of the total relative densities, to reveal the best explanatory variable of their distributions and abundances. After a skewness check through a Draftsman plot, the variables $\mathrm{NO}_{\mathrm{x}}$ and $\mathrm{PO}_{4}$ were log-transformed prior to the analysis. Several significant Spearman correlations were found: accumulation height and leaf litter DW $\left(r_{s}=0.81, N=24, P=0.022\right)$ and wind gust velocity and wind gust quantity $\left(r_{s}=0.96, N=24, P<0.001\right)$. Therefore accumulation height and wind gust quantity were excluded from the BEST analysis.

All the above mentioned analysis were performed with the Primer 6.1.11 software (Clarke and Gorley, 2006) with PERMANOVA add-on software (Anderson et al., 2008). A significance level of $P<0.05$ was used for univariate analysis and $P<0.001$ for multivariate analysis, due to the numerous comparisons in the multiple analyses of variance. Graphs were constructed in GraphPad 5.03 for Windows (GraphPad Software, San Diego California USA).

\section{Results}

\subsection{Environmental data: macrophytodetritus characterisation}

The month of October had the highest detritus accumulation height of $27 \pm 4.6 \mathrm{~cm}$ (average \pm standard deviation, henceforth used as notation) in OSCE compared to $5.0 \pm 0.0 \mathrm{~cm}$ at the same site in August 
(Fig. 1). Detritus accumulation height differed significantly over months (Table 1). Pair-wise post-hoc tests for detritus accumulation height revealed that October differed significantly from all other months and that May and August also significantly differed (Table 1).

The leaf litter dry weight showed a maximum average dry weight in October of $2287.6 \pm 617.9 \mathrm{gDW} \cdot \mathrm{m}^{-2}$ for OSCE (representing $90.7 \%$ of macrophytodetritus) and $1994.7 \pm 860.1 \mathrm{gDW} \cdot \mathrm{m}^{-2}$ for PORT (representing $66.1 \%$ of macrophytodetritus). The lowest leaf litter dry weight was found in August with $452.1 \pm 295.9 \mathrm{gDW} \cdot \mathrm{m}^{-2}$ (representing $73.1 \%$ of macrophytodetritus) and $452.5 \pm 98.8 \mathrm{gDW} \cdot \mathrm{m}^{-2} \mathrm{~g}$ (representing $48.2 \%$ of macrophytodetritus) for OSCE and PORT, respectively (Fig. 1). The factor month showed to be significant especially for October compared to May and August (pair-wise post-hoc test).

The leaf litter epiphyte DW was the highest in October with $233.6 \pm 18.2 \mathrm{gDW} \cdot \mathrm{m}^{-2}$ for OSCE and $336.9 \pm 158.2 \mathrm{gDW} \cdot \mathrm{m}^{-2}$ for PORT, representing $9.3 \%$ and $11.2 \%$ of the total macrophytodetritus. Regarding the macrophytodetritus composition, the highest leaf litter epiphyte DW contribution was found in August for PORT (representing $19.2 \%$ of macrophytodetritus) and for OSCE (representing $10.7 \%$ of macrophytodetritus). Both month and site factors showed a significant effect (Table 1). The pair-wise post-hoc test revealed that October differed significantly from the other months. There was a significant difference in site for the month of February.

The living $P$. oceanica DW was the highest in October in site PORT with $623.5 \pm 284.9 \mathrm{gDW} \cdot \mathrm{m}^{-2}$ and May in site PORT with $262.2 \pm 111.8 \mathrm{gDW} \cdot \mathrm{m}^{-2}$, representing respectively $20.6 \%$ and $22.4 \%$ of the total macrophytodetritus (Fig. 1). The lowest biomass was observed in February in site OSCE with $12.5 \pm 10.9 \mathrm{gDW} \cdot \mathrm{m}^{-2}$ expressing $1.4 \%$ of the total macrophytodetritus biomass. No living P. oceanica DW was found in October OSCE (Fig. 1). All time, site and interaction factors had significant effects. The PERMDISP analysis of the lowest interaction factor was not revealed to be significant.

Drift macroalgae were absent in both sites in February and in the OSCE site in October. The highest drift macroalgae DW was found in May in the PORT site $\left(106.5 \pm 40.5 \mathrm{gDW} \cdot \mathrm{m}^{-2}\right)$ representing $9.1 \%$ of the total macrophytodetritus biomass. As for living $P$. oceanica DW, all factors were found to be significant except the lowest interaction factor (Table 1).

\subsection{Environmental data: abiotic factors}

Median wind gust velocity reached a maximum during February $\left(24.5 \mathrm{~m} \cdot \mathrm{s}^{-1}\right)$ and October $\left(22.4 \mathrm{~m} \cdot \mathrm{s}^{-1}\right)$ (Fig. 2). The median wind gust velocity varied amongst months in decreasing order (OSCE, PORT): February $\left(12.1 \mathrm{~m} \cdot \mathrm{s}^{-1}, 12.4 \mathrm{~m} \cdot \mathrm{s}^{-1}\right)>$ October $\left(9.6 \mathrm{~m} \cdot \mathrm{s}^{-1}\right.$, $\left.9.6 \mathrm{~m} \cdot \mathrm{s}^{-1}\right)>$ May $\left(6.8 \mathrm{~m} \cdot \mathrm{s}^{-1}, 6.5 \mathrm{~m} \cdot \mathrm{s}^{-1}\right)>$ August $\left(4.4 \mathrm{~m} \cdot \mathrm{s}^{-1}\right.$, $4.4 \mathrm{~m} \cdot \mathrm{s}^{-1}$ ) (Fig. 2). The wind gust quantity varied with the same

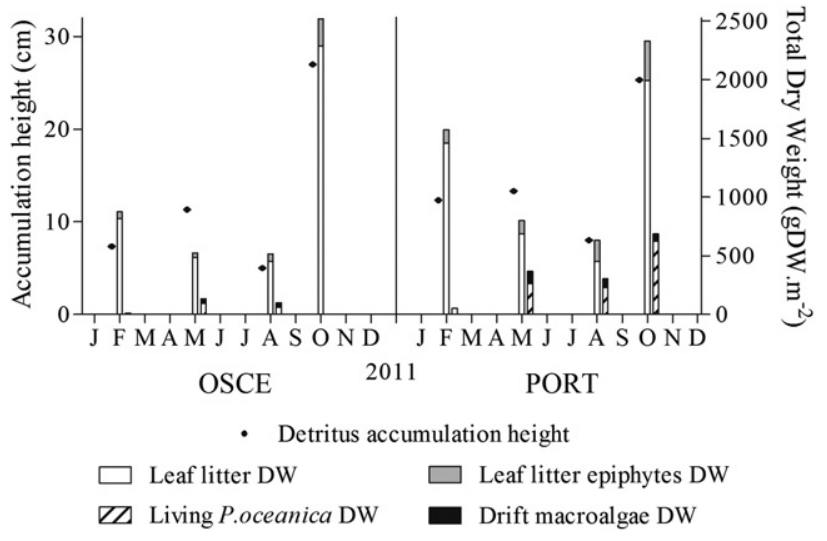

Fig. 1. Macrophytodetritus accumulation height represented in $\mathrm{cm}$ above the sea floor on the left y-axis. Dry weights (DW) of leaf litter, leaf litter epiphytes, living P. oceanica and drift macroalgae are represented on the right y-axis. $N=3$. decreasing trend (OSCE, PORT): February $(43.2 \%, 41.4 \%)>$ October (39.2\%, 39.4\%) > May (23.8\%, 23.6\%) > August (15.2\%, 11.6\%) (Fig. 2). Both median wind gust velocity and wind gust quantity showed a significant effect with the factor month but not for the site and interaction factors (Table 1 ).

The oxygen concentration of the water inside the macrophytodetritus (WI) was always lower than the concentration in the water column (WC) and the water just above the macrophytodetritus (WJA). The latter two were always in the same range between 190 and $250 \mu \mathrm{M}$ (Fig. 3A). For the litter values at least one replicate of each sample was always under the hypoxia limit, defined by Middelburg and Levin (2009), explaining why the averaged $\mathrm{O}_{2}$ concentrations were two to ten times lower than those of the water column and the water just above the litter. $\mathrm{NO}_{\mathrm{x}}$ concentrations showed a high variability (Fig. 3B). Nevertheless in February a noticeable increase of the water column $\mathrm{NO}_{\mathrm{x}}$ concentration is visible next to a decrease in interstitial water content from May onwards. $\mathrm{NH}_{4}$ concentrations were at least ten times higher in the interstitial water (IW) than all other positions, except for the February OSCE sample where a measurement error might have occurred (Fig. 3C). The $\mathrm{PO}_{4}$ concentrations showed no distinct trend apart from the higher concentration in the interstitial water with the exception of the February samples (Fig. 3D).

The 3-way PERMANOVA with all nutrient and oxygen concentrations was significant for all factors and interactions except for the month-site-position interaction factor with $\mathrm{NO}_{\mathrm{x}}$, the site-position interaction factor with oxygen and $\mathrm{NO}_{\mathrm{x}}$ and month-position with oxygen (Table 2). PERMDISP's for all the lowest interaction factors turned out to be significantly different, indicating that the variation within all factors and interactions was due to the dispersion effect and perhaps the location effect as well. All pair-wise correlations between abiotic factors were non-significant, except for wind gust velocity with $\mathrm{WI} \mathrm{O}_{2}$ concentration $\left(r_{s}=0.74, N=24, P=0.046\right)$ and with leaf litter DW $\left(r_{s}=0.77, N=24, P=0.028\right)$.

\subsection{Meiofauna communities}

At a higher taxon level, relative meiofauna composition revealed a clear dominance of Copepoda. Over all months, copepods represented $46.5 \pm 14.6 \%$ (OSCE) and $49.4 \pm 22.2 \%$ (PORT) of the meiofauna with a minimum in February and a maximum in August. The second most abundant taxon was Nematoda with $20.3 \pm 10.1 \%$ in OSCE and $14.8 \pm 4.9 \%$ in PORT. The lowest relative abundance was present in August and the highest was in October for the OSCE site and May for the PORT site. The Copepoda/Nematoda ratio was high in August (8.6) and relatively equal throughout the other seasons: October (2.3), February (2.0) and May (1.8). The remaining taxa encountered in decreasing order, were nauplius larvae (15.7\%), Amphipoda (4.9\%), Turbellaria (4.5\%), copepodites (3.7\%), Polychaeta $(<3 \%)$, Ostracoda, Isopoda, Halacaroidea, Tardigrada, Gastropoda, Kinorincha, Leptostraca, Cumacea, Gastrotricha, Oligochaeta, Tanaidacea, Cnidaria, Chaetognatha, Decapoda larvae and Pycnogonida.

The multivariate analysis showed no effect of the site factor or its interaction, and only showed an effect of month (2-way PERMANOVA, $F$ $\left.{ }^{\prime}(3,16)=6.7, P<0.001\right)$ on the meiofauna assemblage. The principal coordinate analysis (PCO) of meiofauna taxa composition showed a vague temporal separation (Fig. 4A).

The total number of individuals reached their maximum in May for the OSCE site $\left(60,564\right.$ indiv. $\left.\mathrm{m}^{-2}\right)$ and in August for the PORT site (78,062 indiv. $\left.\mathrm{m}^{-2}\right)$. In October for OSCE $\left(34,462\right.$ indiv. $\left.\mathrm{m}^{-2}\right)$ and in February for PORT $\left(31,025\right.$ indiv. $\left.\mathrm{m}^{-2}\right)$ a minimum total meiofauna amount was reached (Fig. 5A). Meiofaunal standardisation towards gram leaf litter dry weight yielded the same maxima. The month of October returned low numbers of organisms per gram leaf litter in both sites (Fig. 5B). The univariate 2-way PERMANOVA on total meiofauna per $\mathrm{m}^{2}$ displayed no significant differences in either factors (month, site) or interactions. In terms of total meiofaunal abundance 
Table 1

Two-way factorial PERMANOVA of environmental variables: detritus and wind descriptors; $F^{\prime}=$ pseudo- $F$ value. DW $=$ dry weight.

\begin{tabular}{|c|c|c|c|c|}
\hline Factors and interaction & Leaf litter DW & Leaf litter epiphytes DW & Drift macroalgae DW & Living $P$. oceanica DW \\
\hline $\begin{array}{l}\text { Month } \\
\text { Site } \\
\text { Month } \times \text { site }\end{array}$ & $\begin{array}{l}F_{(3,16)}^{\prime}=12.30 P<0.001^{* * *} \\
F_{(1,16)}^{\prime}=0.40 P=0.532 \\
F_{(3,16)}^{\prime}=0.80 P=0.525\end{array}$ & $\begin{array}{l}F_{(3,16)}^{\prime}=8.96 P<0.001^{* * *} \\
F_{(1,16)}^{\prime}=6.41 P=0.021^{*} \\
F_{(3,16)}^{\prime}=0.39 P=0.783\end{array}$ & $\begin{array}{l}F_{(3,16)}^{\prime}=15.14 P<0.001^{* * *} \\
F_{(1,16)}^{\prime}=28.68 P<0.001^{* * *} \\
F_{(3,16)}^{\prime}=3.59 P=0.043^{*}\end{array}$ & $\begin{array}{l}F_{(3,16)}^{\prime}=6.21 P=0.008^{* *} \\
F_{(1,16)}^{\prime}=28.93 P<0.001^{* * *} \\
F_{(3,16)}^{\prime}=7.71 P=0.002^{* *}\end{array}$ \\
\hline Factors and interaction & \multicolumn{2}{|c|}{ Detritus accumulation height } & Wind gust velocity & Wind gust quantity \\
\hline $\begin{array}{l}\text { Month } \\
\text { Site } \\
\text { Month } \times \text { site }\end{array}$ & \multicolumn{2}{|c|}{$\begin{array}{l}F_{(3,16)}^{\prime}=28.30 P<0.001^{\text {*** }} \\
F_{(1,16)}^{\prime}=1.64 P=0.220 \\
F_{(3,16)}^{\prime}=0.74 P=0.543\end{array}$} & $\begin{array}{l}F_{(3,16)}^{\prime}=372.63 P<0.001^{\text {*** }} \\
F_{(1,16)}^{\prime}=0.01 P=1.000 \\
F_{(3,16)}^{\prime}=0.05 P=0.666\end{array}$ & $\begin{array}{l}F_{(3,16)}^{\prime}=435.65 P<0.0011^{\text {*** }} \\
F_{(1,16)}^{\prime}=3.90 P=0.068 \\
F_{(3,16)}^{\prime}=1.76 P=0.192\end{array}$ \\
\hline
\end{tabular}

per gram dry weight, the factor site had no significant effect, but the factor month (2-way PERMANOVA, $\left.F_{(3,16)}^{\prime}=12.1, P<0.001\right)$ and the interaction factor (2-way PERMANOVA, $\left.F^{\prime}(3,16)=4.8, P<0.001\right)$ had a highly significant effect. The PERMDISP for the interaction factor was not significant and the pair-wise post-hoc test revealed that only May and August were not significantly different.

The global multivariate BEST analysis revealed that wind gust velocity was the best explanatory variable $(r h o=0.669)$ for the meiofaunal taxa assemblage, followed by its combination with the $\mathrm{WI} \mathrm{NO}_{\mathrm{x}}$ concentrations ( $r h o=0.587$ ). The tertiary best explanatory correlation was the combination of wind gust velocity and $\mathrm{WI} \mathrm{NH}_{4}$ concentration $($ rho $=0.535)$. Oxygen concentration $\left(\mathrm{WI} \mathrm{O}_{2}\right)$ correlation with all taxa abundances gave only one significant outcome (Amphipoda, $\left.r_{s}=-0.809, N=24, P=0.015\right)$. Correlating wind gust velocity with the different taxa abundances gave no significant Spearman correlation, with the exception of the Copepoda taxa $\left(r_{s}=-0.74, N=\right.$ $24, P=0.046)$. The copepodite correlation was not significant, nonetheless the $p$-value was close to the significance threshold level $\left(r_{s}=\right.$ $-0.69, N=24, P=0.069$ ).

\subsection{Harpacticoid copepod species composition}

In total 44 different species belonging to four copepod orders were identified in the macrophytodetritus accumulations under study (Table 3). The majority of species (41) belonged to the order of the

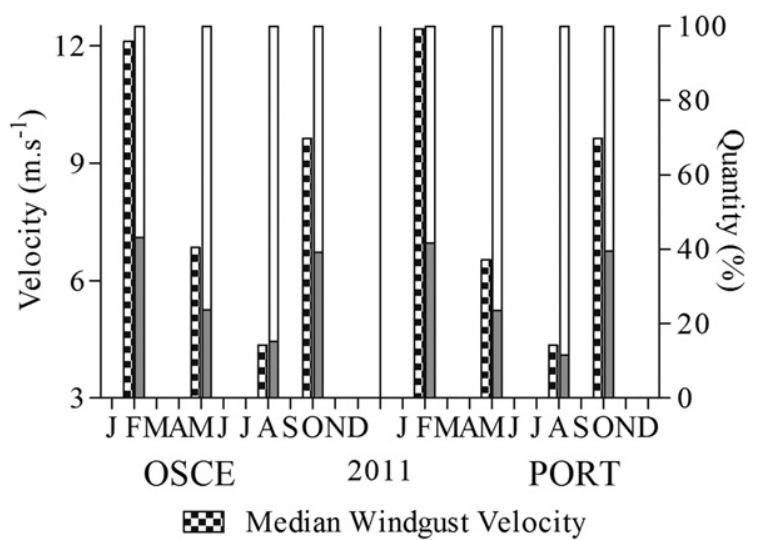

\section{Windgust present $\square$ Windgust absent}

Fig. 2. Wind gusts (selected as winds from North to East, with a velocity $>3.06 \mathrm{~m} \cdot \mathrm{s}^{-1}$ ) represented by their median velocity (during the 4 week's timeframe prior to sampling) on the left $y$-axis and the quantity of the wind gusts compared to all winds measured in percentages on the right $y$-axis.
Harpacticoida, representing $87.2 \pm 10.0 \%$, while three species belonged to the orders Calanoida, Cyclopoida and Syphonostomatoida. Within those three orders, species other than those given in Table 3 were found only in a juvenile state and therefore were not included in the species list. The most diverse harpacticoid families were Miraciidae and Tisbidae that were represented by four and five different species, respectively. The family Tisbidae was present in the highest absolute densities.

Principal coordinate analysis (PCO) of harpacticoid copepod species showed a strong seasonal separation (Fig. 4B). In each month, clusters per site could be detected except for February and October. The separation by months was supported by a multivariate PERMANOVA $(P<0.001$; Table 4).

SIMPER results comparing months showed that one species (Tisbe furcata) was always amongst the top five similarity contributors. Ectinosoma cf. dentatum was ranked important in all months except in May. Diosaccus tenuicornis, Idyella exigua, Tisbe ensifer and Ameira longipes were ranked as important contributors in at least two months (Table 4). In May (53.6\% similarity) both sites showed the lowest cumulative contribution of the first five contributors (50.7\%; Table 4). The highest dissimilarity (75.4\% dissimilarity) was found between May and October. The two lowest dissimilarities were found between February and October with a dissimilarity of $38.9 \%$. The multivariate PERMANOVA analysis showed no separation per site $(P=0.014$; Table 4). Over all months, four of the five most contributing species (SIMPER) were found in both sites. A. longipes, Ectinosoma cf. dentatum, T. ensifer and T. furcata accounted together for $64.3 \%$ in OSCE and $65.0 \%$ in PORT (Table 4).

The samples from the month of May harboured the highest species richness $(S)$ in terms of harpacticoid copepod species in OSCE $(24.7 \pm$ $2.1)$ and in PORT $(20.0 \pm 4.6)$. The lowest $S$ value was noted in October for OSCE $(9.0 \pm 1.0)$ and in February for PORT (12.3 \pm 0.6$)$. Species richness differed significantly for every factor and interaction (Table 5), with a non-significant PERMDISP of the interaction factor $(P=0.324)$. The heterogeneity of $\mathrm{N}_{1}$ (more sensitive to the number of abundant species) and $\mathrm{N}_{2}$ (giving more weight to the dominant species) differed significantly for the factor month (PERMANOVA) (Table 5).

Standardisation of harpacticoid copepod abundances towards gram dry weight leaf litter was significantly affected by the factor month and its interaction with the factor site. The interaction had a nonsignificant PERMDISP $(P=0.360)$. However, when copepod densities were standardised by square metre, only the factor month showed an effect (Table 5). A pair-wise test revealed that only February-May and May-October were not significantly different from other months.

The global multivariate BEST analysis found wind gust velocity to be the best explanatory variable for the harpacticoid copepod assemblage ( rho $=0.510$ ), followed by wind gust velocity combined with leaf litter DW (rho $=0.425$ ). The tertiary explanatory variable was the combination of the latter two and the drift macroalgae DW 

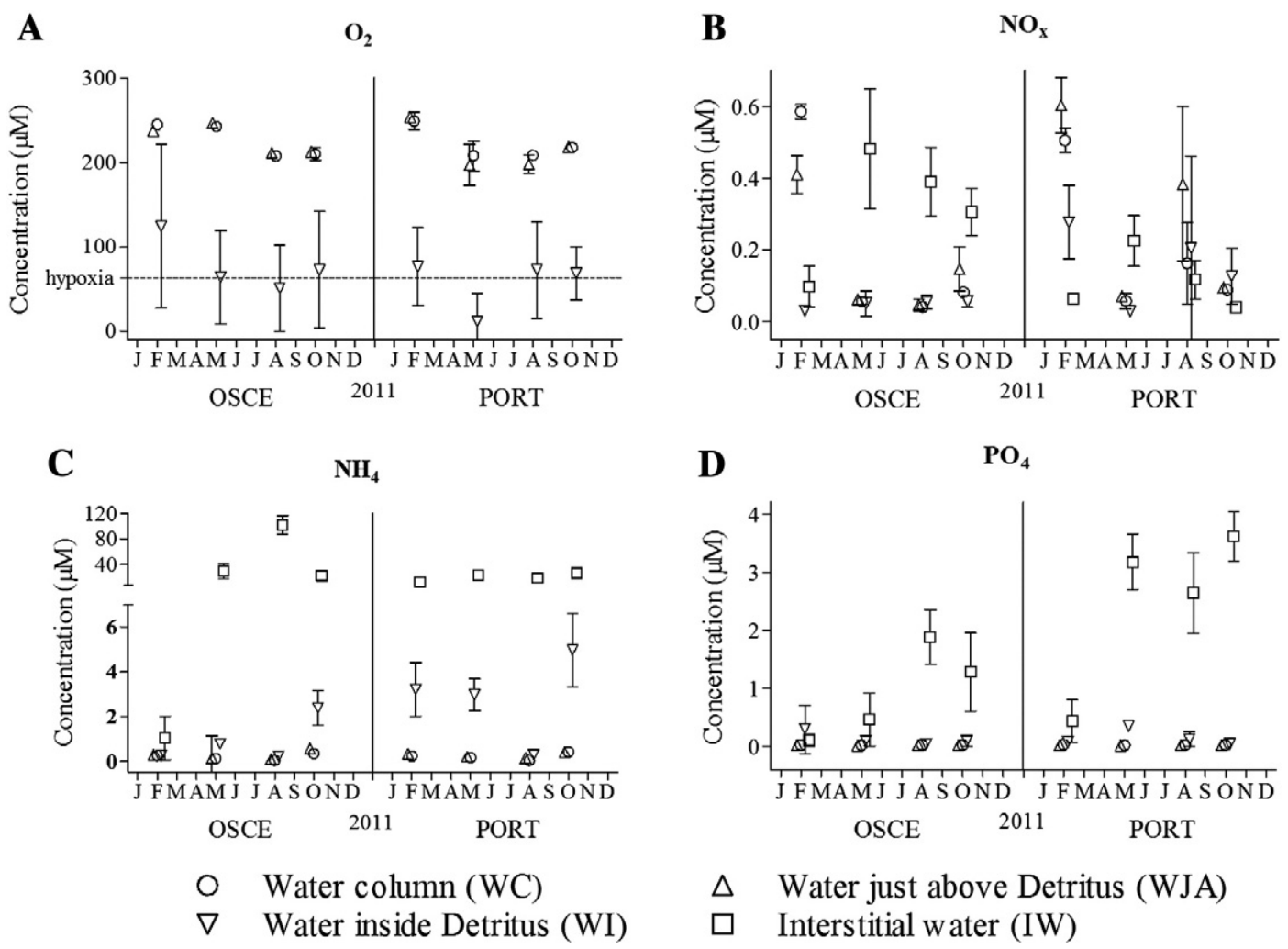

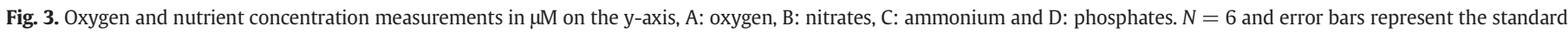
deviation.

(rho $=0.409$ ). Harpacticoid $S$ and environmental factors yielded a significant correlation for leaf litter DW $\left(r_{s}=-0.82, N=24, P=\right.$ 0.011).

The five univariate BEST analyses of the five most dominant harpacticoids yielded different best explanatory variables. The T. furcata (19.0\% of all harpacticoids) test revealed primary variables that were a combination of leaf litter DW, wind velocity and Epi/Lit ratio (rho $=0.503$ ). The Ectinosoma cf. dentatum $(8.9 \%$ of all harpacticoids) test revealed primary variables that were a combination of leaf litter epiphytes DW and living P. oceanica DW (rho $=0.149$ ). The T. ensifer (8.6\% of all harpacticoids) and A. longipes ( $8.4 \%$ of all harpacticoids) test displayed combinations of drift macroalgae DW and wind velocity as the best explanatory variables (rho $=0.480$ and rho $=0.305$, respectively). The Diosaccus tenuicornis $(4.5 \%$ of all harpacticoids) test found a combination of leaf litter epiphytes DW, WI $\mathrm{O}_{2}$ concentration and Epi/Lit ratio $($ rho $=0.144)$ as the best explanatory variables.

\section{Discussion}

\subsection{Harpacticoid copepod species assemblage in detritus}

According to Hicks and Coull (1983), harpacticoid copepods are regularly encountered as the most dominant and diverse meiobenthic taxon in phytal substrata. The comparison between macrophytodetritus accumulations and seagrass canopy revealed similar trends of the harpacticoid copepod community. The macrophytodetritus accumulations harboured the same density in order of magnitude $\left(10^{4}\right.$ $10^{5}$ indiv. $\mathrm{m}^{-2}$ ) as P. oceanica meadows (Mascart et al., 2013; Novak, 1982). The diversity, around 30 to 50 harpacticoid species, was similar to other phytal ecosystems (De Troch et al., 2008; Heip et al., 1983; Hicks, 1977; Johnson and Scheibling, 1987; Steinarsdóttir et al., 2003). In this study, five abundant harpacticoid species were found belonging to different ecological and morphological groups. Two of them belonged to the phytal-swimmers group (Tisbidae family, genus Tisbe), known as

Table 2

Three-way factorial PERMANOVA of nutrients and oxygen environmental variables; $F^{\prime}=$ pseudo- $F$ value.

\begin{tabular}{|c|c|c|c|c|}
\hline Factors and interaction & $\mathrm{NH}_{4}$ & $\mathrm{NO}_{\mathrm{x}}$ & $\mathrm{PO}_{4}$ & $\mathrm{O}_{2}$ \\
\hline Month (Mo) & $F_{(3,160)}^{\prime}=83.8 P<0.001^{*}$ & $F_{(3,160)}^{\prime}=38.9 P<0.001^{*}$ & $F_{(3,160)}^{\prime}=46.9 P<0.001^{*}$ & $F_{(3.120)}^{\prime}=16.6 P<0.001^{*}$ \\
\hline Site $(\mathrm{Si})$ & $F_{(1,160)}^{\prime}=50.5 P<0.001^{*}$ & $F_{(1,160)}^{\prime}=18.5 P<0.001^{*}$ & $F_{(1,160)}^{\prime}=120.6 P<0.001^{*}$ & $F_{(1,120)}^{\prime}=17.4 P<0.001^{*}$ \\
\hline Position (Po) & $F_{(3,160)}^{\prime}=584.9 P<0.001^{*}$ & $F_{(3,160)}^{\prime}=3.5 P<0.015$ & $F_{(3,160)}^{\prime}=572.2 P<0.001^{*}$ & $F_{(2,120)}^{\prime}=312.3 P<0.001^{*}$ \\
\hline $\mathrm{Mo} \times \mathrm{Si}$ & $F^{\prime}{ }_{(3,160)}=89.3 P<0.001^{*}$ & $F_{(3,160)}^{\prime}=18.5 P<0.001^{*}$ & $F_{(3,160)}^{\prime}=26.6 P<0.001^{*}$ & $F_{(3,120)}^{\prime}=15.6 P<0.001^{*}$ \\
\hline Mo $\times$ Po & $F_{(9,160)}^{\prime}=94.5 P<0.001^{*}$ & $F_{(9,160)}^{\prime}=3.5 P<0.001^{*}$ & $F_{(9,160)}^{\prime}=53.6 P<0.001^{*}$ & $F_{(6,120)}^{\prime}=2.3 P=0.038$ \\
\hline $\mathrm{Si} \times \mathrm{Po}$ & $F^{\prime}{ }_{(3,160)}=68.3 P<0.001^{*}$ & $F_{(3,160)}^{\prime}=1.1 P=0.367$ & $F_{(3,160)}^{\prime}=117.1 P<0.001^{*}$ & $F_{(2,120)}^{\prime}=2.7 P=0.074$ \\
\hline $\mathrm{Mo} \times \mathrm{Si} \times \mathrm{Po}$ & $F_{(9,160)}^{\prime}=82.7 P<0.001^{*}$ & $F_{(9,160)}^{\prime}=1.1 P=0.367$ & $F_{(9,160)}^{\prime}=21.2 P<0.001^{*}$ & $F_{(6,120)}^{\prime}=4.7 P<0.001^{*}$ \\
\hline
\end{tabular}

$*=P<0.001=$ significant 
A

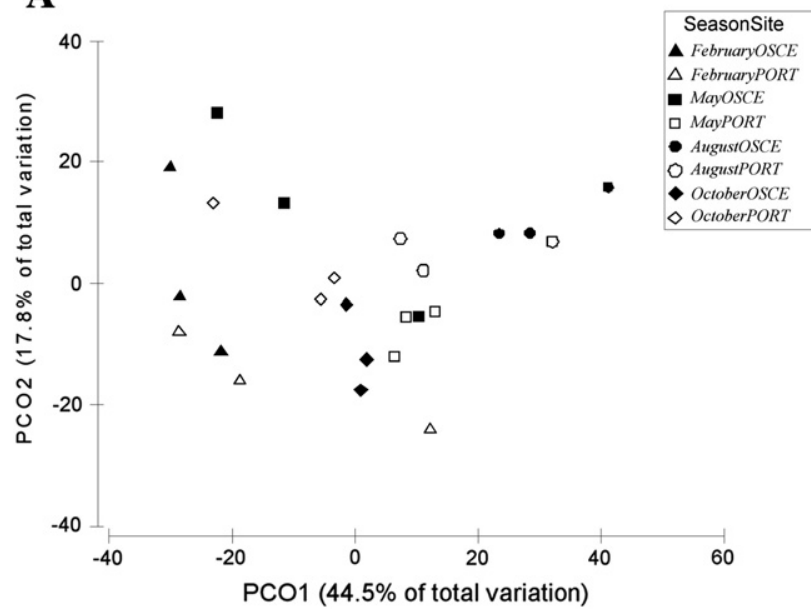

B

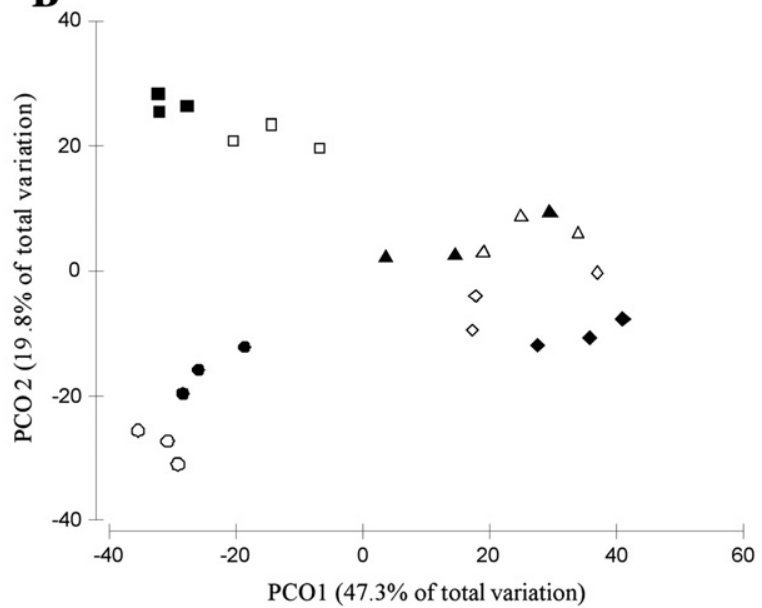

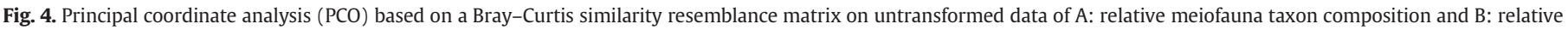

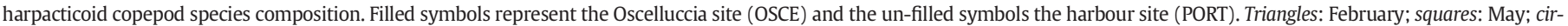
cles: August and diamonds: October.

very good swimmers. Two belonged to the phytal group sensu strictu (A. longipes and Diosaccus tenuicornis) and one was a typical mesopsammic species (Giere, 2009) of the Ectinosomatidae family (Ectinosoma cf. dentatum). The abundant species found in the macrophytodetritus are cosmopolitan and are recorded in other habitats as well (Bell et al., 1987; Colangelo et al., 1996; Giere, 2009; Steinarsdóttir et al., 2003; Walters, 1991). During the calmest and lowest accumulation months of May and August, harpacticoid species were abundant and diverse. This rise coincides with the
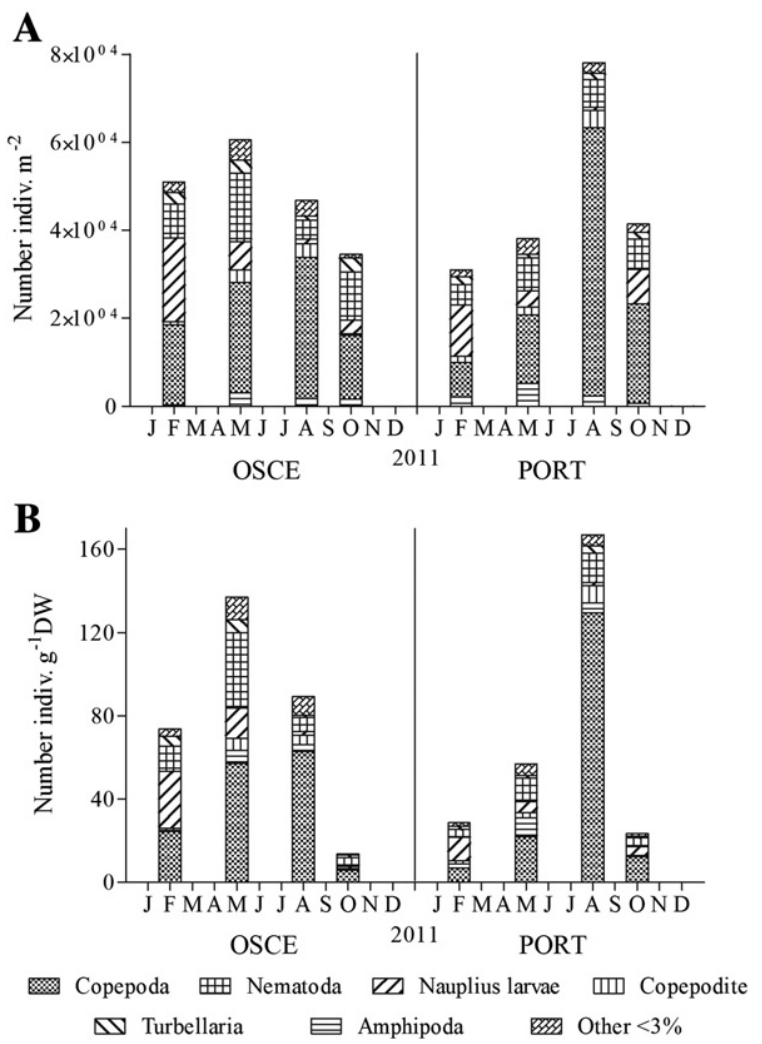

Fig. 5. Main meiofauna taxa densities per sampled month and site with left, Oscelluccia (OSCE) and right, harbour (PORT). A: abundance per $\mathrm{m}^{2}$ and $\mathrm{B}$ : abundance per $\mathrm{g}$ dry weight (DW) leaf litter. rise in primary production and increase in densities of mostly phytal harpacticoids such as A. longipes, Diosaccus tenuicornis, Sarsamphiascus tenuiremis, Dactylopusia tisboides and Porcellidium ovatum. In months with high leaf litter biomass (February and October), $T$. furcata and T. ensifer dominated the community. Both species are phytal-swimmers and seemed more adapted to the higher hydrodynamic disturbance. The distribution of the mesopsammic Ectinosoma cf. dentatum on the other hand seemed to be linked, although with little strength (low rho), to the amount of leaf litter epiphytes and living $P$. oceanica present. Henceforth, we could assume that Ectinosoma cf. dentatum migrated into the macrophytodetritus accumulation to avoid low oxygen levels in the sediment underneath or to search for more accessible food. Harpacticoids are known to feed on a wide variety of food sources (Hicks and Coull, 1983; Lee et al., 1977), displaying species-specific food preferences (Buffan-Dubau and Carman, 2000; De Troch et al., 2012; Decho and Castenholz, 1986; Pace and Carman, 1996; Wyckmans et al., 2007). Hicks and Coull (1983) stated that the existence of a wide variety of morphologically similar species in one habitat is allowed as a consequence of harpacticoids' selective feeding. This all points to the possibility that the harpacticoid community is mainly associated with the macrophytodetritus for food availability and shelter (Coull and Wells, 1983).

Leaf litter has been recognised as a food source for harpacticoid copepods (Meyer and Bell, 1989) since detrital forms of organic material were more palatable and more accessible than fresh material for consumers (Edgar et al., 1994; Enriquez et al., 1993; Harrison and Mann, 1975). It is thus possible that macrophytodetritus accumulations yield a more readily available food for harpacticoids in contrast to other habitats and this will attract them (Norkko and Bonsdorff, 1996). However, laboratory and field studies stated that the meiofaunal detritus-feeders primarily rely on the micro-epiphytes associated with the leaf litter surface (Carman and Thistle, 1985; Hicks and Coull, 1983; Ustach, 1982). In this study site, the leaf litter epiphytes consisted of an abundant community of micro-epiphytic organisms such as bacteria, marine fungi, protozoa, micro- and detrital-algae (Lepoint et al., 2006). This complex community of leaf litter epiphytes created micro-scale variability in resources and shelter for the associated fauna. However, no difference in terms of epiphytic members was found in the present study and consequently we can state that the leaf litter epiphytes represent a bulk of macro- and micro-epiphytes. In order to obtain more information on the species-specific feeding preference of harpacticoid copepods additional investigations (e.g. food source tracing experiment) are certainly required. 
Table 3

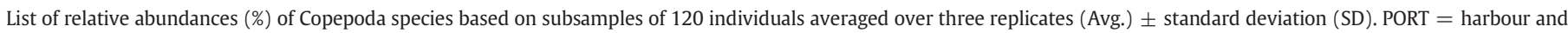
$\mathrm{OSCE}=$ Oscelluccia. Species with bold font are the five dominant harpacticoids.

\begin{tabular}{|c|c|c|c|c|c|c|c|c|}
\hline & \multicolumn{2}{|l|}{ February } & \multicolumn{2}{|l|}{ May } & \multicolumn{2}{|l|}{ August } & \multicolumn{2}{|l|}{ October } \\
\hline & \multirow{2}{*}{$\frac{\mathrm{OSCE}}{\text { Avg. } \pm \text { SD }}$} & \multirow{2}{*}{$\frac{\text { PORT }}{\text { Avg. } \pm \text { SD }}$} & \multirow{2}{*}{$\frac{\mathrm{OSCE}}{\text { Avg. } \pm \text { SD }}$} & \multirow{2}{*}{$\frac{\text { PORT }}{\text { Avg. } \pm \text { SD }}$} & OSCE & PORT & OSCE & PORT \\
\hline & & & & & Avg. \pm SD & Avg. \pm SD & Avg. \pm SD & Avg. \pm SD \\
\hline Harpacticoida & $0 \pm 0$ & $0 \pm 0$ & $0 \pm 0$ & $0 \pm 0$ & $0 \pm 0$ & $0 \pm 0$ & $0 \pm 0$ & $0 \pm 0$ \\
\hline Ameiridae & $0 \pm 0$ & $0 \pm 0$ & $0 \pm 0$ & $0 \pm 0$ & $0 \pm 0$ & $0 \pm 0$ & $0 \pm 0$ & $0 \pm 0$ \\
\hline Ameira longipes (Boeck, 1865) & $2.2 \pm 0.9$ & $8.4 \pm 1.8$ & $2.2 \pm 1.4$ & $8.5 \pm 1.5$ & $0 \pm 0$ & $0 \pm 0$ & $0 \pm 0$ & $0.8 \pm 1.3$ \\
\hline Ancorabolidae & $0 \pm 0$ & $0 \pm 0$ & $0 \pm 0$ & $0 \pm 0$ & $0 \pm 0$ & $0 \pm 0$ & $0 \pm 0$ & $0 \pm 0$ \\
\hline Laophontodes bicornis (Scott A., 1896) & $0.8 \pm 0.7$ & $0 \pm 0$ & $1.8 \pm 1.2$ & $0.8 \pm 0.7$ & $1.4 \pm 1.5$ & $1 \pm 0.9$ & $0 \pm 0$ & $1.2 \pm 1.2$ \\
\hline Laophontodes typicus (Scott T., 1894) & $0.8 \pm 1.4$ & $0 \pm 0$ & $0 \pm 0$ & $0.3 \pm 0.6$ & $0 \pm 0$ & $0 \pm 0$ & $0 \pm 0$ & $0 \pm 0$ \\
\hline Canuelidae & $0 \pm 0$ & $0 \pm 0$ & $0 \pm 0$ & $0 \pm 0$ & $0 \pm 0$ & $0 \pm 0$ & $0 \pm 0$ & $0 \pm 0$ \\
\hline Canuella furcigera (Sars G.O., 1903) & $1.8 \pm 0.9$ & $0.4 \pm 0.7$ & $0 \pm 0$ & $0 \pm 0$ & $0 \pm 0$ & $0 \pm 0$ & $0 \pm 0$ & $0 \pm 0$ \\
\hline Cletodidae & $0 \pm 0$ & $0 \pm 0$ & $0 \pm 0$ & $0 \pm 0$ & $0 \pm 0$ & $0 \pm 0$ & $0 \pm 0$ & $0 \pm 0$ \\
\hline Cletodes limicola (Brady, 1872) & $0 \pm 0$ & $0.4 \pm 0.7$ & $0 \pm 0$ & $0 \pm 0$ & $0 \pm 0$ & $0 \pm 0$ & $0 \pm 0$ & $0 \pm 0$ \\
\hline Cylindropsyliidae & $0 \pm 0$ & $0 \pm 0$ & $0 \pm 0$ & $0 \pm 0$ & $0 \pm 0$ & $0 \pm 0$ & $0 \pm 0$ & $0 \pm 0$ \\
\hline Cylindropsyllus laevis (Brady, 1880) & $0 \pm 0$ & $0 \pm 0$ & $0 \pm 0$ & $0 \pm 0$ & $0 \pm 0$ & $0 \pm 0$ & $0.4 \pm 0.7$ & $0 \pm 0$ \\
\hline Dactylopusiidae & & & & & & & & \\
\hline Dactylopusia tisboides (Claus, 1863) & $2.1 \pm 1.4$ & $1.4 \pm 2.4$ & $12.9 \pm 4.4$ & $3.9 \pm 4.3$ & $6.7 \pm 5.6$ & $5.9 \pm 1.7$ & $0 \pm 0$ & $0 \pm 0$ \\
\hline Diarthrodes minutus (Claus, 1863) & $2.1 \pm 0.6$ & $1.3 \pm 0$ & $2.2 \pm 1.4$ & $1.5 \pm 1.5$ & $0 \pm 0$ & $0 \pm 0$ & $0 \pm 0$ & $0 \pm 0$ \\
\hline Paradactylopodia brevicornis (Claus, 1866) & $2.1 \pm 1.4$ & $0.9 \pm 0.8$ & $1 \pm 0.9$ & $0.8 \pm 0.7$ & $1.4 \pm 1.2$ & $1.4 \pm 1.4$ & $0 \pm 0$ & $0 \pm 0$ \\
\hline Ectinosomatidae & $0 \pm 0$ & $0 \pm 0$ & $0 \pm 0$ & $0 \pm 0$ & $0 \pm 0$ & $0 \pm 0$ & $0 \pm 0$ & $0 \pm 0$ \\
\hline Ectinosoma cf. dentatum (Steuer, 1940) & $12.8 \pm 4.8$ & $10.7 \pm 1.7$ & $2.2 \pm 0.4$ & $9.9 \pm 2.7$ & $12.5 \pm 0.5$ & $18.7 \pm 5.2$ & $10.2 \pm 4$ & $4.6 \pm 0.6$ \\
\hline Ectinosoma sp. & $0 \pm 0$ & $0.9 \pm 0.8$ & $0 \pm 0$ & $0.5 \pm 0.8$ & $0.3 \pm 0.6$ & $1 \pm 1.8$ & $0 \pm 0$ & $0.4 \pm 0.7$ \\
\hline Microsetella norvegica (Boeck, 1865) & $0.8 \pm 1.4$ & $0.4 \pm 0.8$ & $0 \pm 0$ & $0.3 \pm 0.6$ & $0.7 \pm 0.6$ & $0.5 \pm 0.9$ & $1.1 \pm 1.9$ & $0.9 \pm 1.5$ \\
\hline Euterpinidae & $0 \pm 0$ & $0 \pm 0$ & $0 \pm 0$ & $0 \pm 0$ & $0 \pm 0$ & $0 \pm 0$ & $0 \pm 0$ & $0 \pm 0$ \\
\hline Euterpina acutifrons (Dana, 1847) & $0 \pm 0$ & $0 \pm 0$ & $0.3 \pm 0.6$ & $0 \pm 0$ & $0 \pm 0$ & $0 \pm 0$ & $0 \pm 0$ & $0 \pm 0$ \\
\hline Hamondiidae & & & & & & & & \\
\hline Ambunguipes rufocincta (Norman in Brady, 1880) & $0 \pm 0$ & $0 \pm 0$ & $3.1 \pm 2.3$ & $0.8 \pm 0.7$ & $0 \pm 0$ & $0 \pm 0$ & $0 \pm 0$ & $0 \pm 0$ \\
\hline Harpacticiidae & $0 \pm 0$ & $0 \pm 0$ & $0 \pm 0$ & $0 \pm 0$ & $0 \pm 0$ & $0 \pm 0$ & $0 \pm 0$ & $0 \pm 0$ \\
\hline Harpacticus littoralis (Sars G.O., 1910) & $3.5 \pm 0.5$ & $0 \pm 0$ & $0.9 \pm 1.5$ & $4.6 \pm 3.5$ & $5.9 \pm 4$ & $3.4 \pm 0.9$ & $1.1 \pm 2$ & $1.2 \pm 2$ \\
\hline Laophontidae & $0 \pm 0$ & $0 \pm 0$ & $0 \pm 0$ & $0 \pm 0$ & $0 \pm 0$ & $0 \pm 0$ & $0 \pm 0$ & $0 \pm 0$ \\
\hline Esola longicauda (Edwards, 1891) & $0 \pm 0$ & $0 \pm 0$ & $0.6 \pm 1.1$ & $0 \pm 0$ & $2.7 \pm 2$ & $3 \pm 2.6$ & $0 \pm 0$ & $0 \pm 0$ \\
\hline Laophonte cornuta (Philippi, 1840) & $0 \pm 0$ & $0.9 \pm 1.5$ & $2.4 \pm 1.2$ & $8.3 \pm 1.6$ & $1.4 \pm 1.2$ & $1 \pm 0.8$ & $0 \pm 0$ & $0 \pm 0$ \\
\hline Paralaophonte brevirostris (Claus, 1863) & $1.2 \pm 2.1$ & $0 \pm 0$ & $6.9 \pm 1.9$ & $3.2 \pm 1.9$ & $4.2 \pm 2.2$ & $2.9 \pm 1.3$ & $0 \pm 0$ & $2.2 \pm 2$ \\
\hline Longipediidae & $0 \pm 0$ & $0 \pm 0$ & $0 \pm 0$ & $0 \pm 0$ & $0 \pm 0$ & $0 \pm 0$ & $0 \pm 0$ & $0 \pm 0$ \\
\hline Longipedia minor (Scott T. \& A., 1893) & $0 \pm 0$ & $0 \pm 0$ & $1.4 \pm 0.6$ & $1.1 \pm 1$ & $0.4 \pm 0.6$ & $0.5 \pm 0.9$ & $0 \pm 0$ & $0 \pm 0$ \\
\hline Metidae & $0 \pm 0$ & $0 \pm 0$ & $0 \pm 0$ & $0 \pm 0$ & $0 \pm 0$ & $0 \pm 0$ & $0 \pm 0$ & $0 \pm 0$ \\
\hline Metis ignea (Philippi, 1843) & $0 \pm 0$ & $0 \pm 0$ & $0 \pm 0$ & $0.3 \pm 0.6$ & $0 \pm 0$ & $0 \pm 0$ & $0.4 \pm 0.7$ & $0 \pm 0$ \\
\hline Miraciidae & $0 \pm 0$ & $0 \pm 0$ & $0 \pm 0$ & $0 \pm 0$ & $0 \pm 0$ & $0 \pm 0$ & $0 \pm 0$ & $0 \pm 0$ \\
\hline Amphiascoides debilis (Giesbrecht, 1881) & $2.2 \pm 0.9$ & $8.4 \pm 1.8$ & $2.2 \pm 1.4$ & $8.5 \pm 1.5$ & $0 \pm 0$ & $0 \pm 0$ & $0 \pm 0$ & $0.8 \pm 1.3$ \\
\hline Amphiascus minutus (Claus, 1863) & $0 \pm 0$ & $0 \pm 0$ & $9.2 \pm 5.3$ & $19.3 \pm 2.2$ & $3.1 \pm 1.7$ & $2.1 \pm 3.6$ & $0 \pm 0$ & $4.1 \pm 2.5$ \\
\hline Sarsamphiascus tenuiremis (Brady, 1880) & $0 \pm 0$ & $0 \pm 0$ & $2.3 \pm 2$ & $1.5 \pm 1.5$ & $13.2 \pm 3.2$ & $13.5 \pm 2.8$ & $0 \pm 0$ & $3.8 \pm 1.3$ \\
\hline Diosaccus tenuicornis (Claus, 1863) & $2.5 \pm 2.1$ & $5.8 \pm 2.9$ & $4.3 \pm 0.8$ & $3.9 \pm 2.3$ & $3.2 \pm 2.9$ & $9.2 \pm 2.9$ & $8.4 \pm 5$ & $3.8 \pm 3.4$ \\
\hline Peltiidae & $0 \pm 0$ & $0 \pm 0$ & $0 \pm 0$ & $0 \pm 0$ & $0 \pm 0$ & $0 \pm 0$ & $0 \pm 0$ & $0 \pm 0$ \\
\hline Alteutha depressa (Claus, 1863) & $2.2 \pm 0.8$ & $0 \pm 0$ & $1.3 \pm 1.1$ & $0 \pm 0$ & $0 \pm 0$ & $0 \pm 0$ & $0 \pm 0$ & $0 \pm 0$ \\
\hline Porcellidiidae & $0 \pm 0$ & $0 \pm 0$ & $0 \pm 0$ & $0 \pm 0$ & $0 \pm 0$ & $0 \pm 0$ & $0 \pm 0$ & $0 \pm 0$ \\
\hline Porcellidium ovatum (Haller, 1879) & $4.4 \pm 1.7$ & $5.8 \pm 2$ & $7.6 \pm 2.2$ & $4.7 \pm 2.9$ & $2.4 \pm 3.4$ & $0 \pm 0$ & $0.5 \pm 0.9$ & $0 \pm 0$ \\
\hline Pseudotachidiidae & & & & & & & & \\
\hline Dactylopodella flava (Claus, 1866) & $0 \pm 0$ & $0 \pm 0$ & $0 \pm 0$ & $0 \pm 0$ & $1.8 \pm 1.6$ & $1.9 \pm 0.7$ & $0 \pm 0$ & $0 \pm 0$ \\
\hline Xouthous laticaudatus (Thompson I.C. \& Scott A., 1903) & $1.2 \pm 2.1$ & $0 \pm 0$ & $0 \pm 0$ & $101 \pm 172.3$ & $6.7 \pm 5.6$ & $5.9 \pm 1.7$ & $0 \pm 0$ & $0 \pm 0$ \\
\hline Tegastidae & $0 \pm 0$ & $0 \pm 0$ & $0 \pm 0$ & $0 \pm 0$ & $0 \pm 0$ & $0 \pm 0$ & $0 \pm 0$ & $0 \pm 0$ \\
\hline Tegastes areolatus (Monard, 1935) & $0 \pm 0$ & $0 \pm 0$ & $0.3 \pm 0.5$ & $0.9 \pm 0.8$ & $0.7 \pm 0.6$ & $0 \pm 0$ & $0.6 \pm 1$ & $1.3 \pm 2.2$ \\
\hline Tegastes falcatus (Norman, 1869) & $1.8 \pm 0.9$ & $0.5 \pm 0.8$ & $1.4 \pm 0.6$ & $0 \pm 0$ & $0 \pm 0$ & $0 \pm 0$ & $0 \pm 0$ & $0 \pm 0$ \\
\hline Tegastes satyrus (Claus, 1860) & $0.5 \pm 0.8$ & $0 \pm 0$ & $0.7 \pm 0.6$ & $2.1 \pm 2.1$ & $2.5 \pm 2.2$ & $2 \pm 1$ & $0 \pm 0$ & $0 \pm 0$ \\
\hline Tetragonicepsidae & $0 \pm 0$ & $0 \pm 0$ & $0 \pm 0$ & $0 \pm 0$ & $0 \pm 0$ & $0 \pm 0$ & $0 \pm 0$ & $0 \pm 0$ \\
\hline Diagoniceps laevis (Willey, 1930) & $0 \pm 0$ & $0 \pm 0$ & $13.2 \pm 18.3$ & $0 \pm 0$ & $0 \pm 0$ & $0 \pm 0$ & $0.6 \pm 1$ & $0.4 \pm 0.7$ \\
\hline Phyllopodopsyllus bradyi (Scott T., 1892) & $0 \pm 0$ & $0 \pm 0$ & $2.2 \pm 0.4$ & $0 \pm 0$ & $2 \pm 3.5$ & $0 \pm 0$ & $0 \pm 0$ & $0.4 \pm 0.7$ \\
\hline Thalestridae & $0 \pm 0$ & $0 \pm 0$ & $0 \pm 0$ & $0 \pm 0$ & $0 \pm 0$ & $0 \pm 0$ & $0 \pm 0$ & $0 \pm 0$ \\
\hline Parathalestris harpactoides (Claus, 1863) & $1.2 \pm 2.1$ & $0 \pm 0$ & $0 \pm 0$ & $0.8 \pm 0.7$ & $0 \pm 0$ & $0 \pm 0$ & $0 \pm 0$ & $0 \pm 0$ \\
\hline Rhynchothalestris helgolandica (Claus, 1863) & $0 \pm 0$ & $0 \pm 0$ & $0 \pm 0$ & $0 \pm 0$ & $0 \pm 0$ & $0 \pm 0$ & $0 \pm 0$ & $1.3 \pm 2.2$ \\
\hline Thalestris rufoviolascens (Claus, 1866) & $0 \pm 0$ & $0 \pm 0$ & $1.1 \pm 0.2$ & $0.3 \pm 0.6$ & $0 \pm 0$ & $0 \pm 0$ & $0 \pm 0$ & $0 \pm 0$ \\
\hline Tisbidae & $0 \pm 0$ & $0 \pm 0$ & $0 \pm 0$ & $0 \pm 0$ & $0 \pm 0$ & $0 \pm 0$ & $0 \pm 0$ & $0 \pm 0$ \\
\hline Idyella exigua (Sars G.O., 1905) & $0 \pm 0$ & $11.2 \pm 4.8$ & $0 \pm 0$ & $0 \pm 0$ & $1.4 \pm 1.6$ & $0 \pm 0$ & $7.1 \pm 1.4$ & $12.2 \pm 2.6$ \\
\hline Tisbe elegantula (Sars G.O., 1905) & $0 \pm 0$ & $0 \pm 0$ & $0.3 \pm 0.5$ & $0 \pm 0$ & $0 \pm 0$ & $0 \pm 0$ & $6.9 \pm 6.8$ & $3.8 \pm 1.5$ \\
\hline Tisbe ensifer (Fischer, 1860) & $23.9 \pm 1$ & $10.6 \pm 2.3$ & $2.9 \pm 1.6$ & $3.6 \pm 3$ & $4.2 \pm 1.9$ & $2.4 \pm 2.1$ & $18.4 \pm 10.1$ & $12.5 \pm 8$ \\
\hline Tisbe furcata (Baird, 1837) & $27 \pm 14.9$ & $36.3 \pm 6.9$ & $5.1 \pm 2.8$ & $13.6 \pm 2$ & $10.5 \pm 1.4$ & $3.4 \pm 0.9$ & $40.3 \pm 1.5$ & $37.2 \pm 7.8$ \\
\hline Sacodiscus littoralis (Sars G.O., 1904) & $0 \pm 0$ & $0 \pm 0$ & $2.4 \pm 1.3$ & $0 \pm 0$ & $0 \pm 0$ & $0 \pm 0$ & $0 \pm 0$ & $0 \pm 0$ \\
\hline Calanoida & & & & & & & & \\
\hline Clausocalanidae & & & & & & & & \\
\hline Pseudocalanus minutus (Krøyer, 1845) & $0.4 \pm 0.7$ & $0.4 \pm 0.8$ & $0 \pm 0$ & $2.8 \pm 4.8$ & $0.4 \pm 0.6$ & $0 \pm 0$ & $0 \pm 0$ & $1.3 \pm 1.3$ \\
\hline Cyclopoida & $0 \pm 0$ & $0 \pm 0$ & $0 \pm 0$ & $0 \pm 0$ & $0 \pm 0$ & $0 \pm 0$ & $0 \pm 0$ & $0 \pm 0$ \\
\hline Cyclopinidae spp. & $17.2 \pm 12.9$ & $9.6 \pm 7.8$ & $13.7 \pm 15.4$ & $26.7 \pm 17.5$ & $15.5 \pm 9.5$ & $21.3 \pm 9.2$ & $1.3 \pm 1.2$ & $4.2 \pm 2.2$ \\
\hline Siphonostomatoida & & & & & & & & \\
\hline Artotrogidae & & & & & & & & \\
\hline Cribropontius normani (Brady \& Robertson D., 1876) & $1.7 \pm 1.9$ & $0.4 \pm 0.7$ & $1.5 \pm 1.6$ & $1 \pm 1.6$ & $0 \pm 0$ & $0 \pm 0$ & $0.6 \pm 1$ & \\
\hline
\end{tabular}


Table 4

Multivariate PERMANOVA and SIMPER results with factors month and site for harpacticoid copepod species contributions. First five contributing species are shown.

\begin{tabular}{|c|c|c|c|c|c|}
\hline \multicolumn{6}{|c|}{ Across factor Month (PERMANOVA: $P<0.001$ ) } \\
\hline \multicolumn{3}{|c|}{ February (75.9\% similarity) } & \multicolumn{3}{|c|}{ May (53.6\% similarity) } \\
\hline Species & $\%$ & cum. \% & Species & $\%$ & cum. \% \\
\hline Tisbe furcata & 32.2 & 32.2 & Amphiascus minutus & 15.3 & 15.3 \\
\hline Tisbe ensifer & 21.3 & 53.5 & Tisbe furcata & 10.2 & 25.5 \\
\hline Ectinosoma cf. dentatum & 12.7 & 66.2 & Dactylopusia tisboides & 9.9 & 35.4 \\
\hline Amphiascoides debilis & 5.9 & 72.0 & Porcellidium ovatum & 7.8 & 43.3 \\
\hline Idyella exigua & 5.5 & 77.5 & Ameira longipes & 7.4 & 50.7 \\
\hline \multicolumn{3}{|c|}{ August (72.5\% similarity) } & \multicolumn{3}{|c|}{ October (72.4\% similarity) } \\
\hline Species & $\%$ & cum. \% & Species & $\%$ & cum. \% \\
\hline Ameira longipes & 24.3 & 24.3 & Tisbe furcata & 49.6 & 49.6 \\
\hline Ectinosoma cf. dentatum & 18.0 & 42.3 & Tisbe ensifer & 13.6 & 63.2 \\
\hline Sarsamphiascus tenuiremis & 14.9 & 57.1 & Idyella exigua & 11.6 & 74.8 \\
\hline Tisbe furcata & 8.0 & 65.1 & Ectinosoma cf. dentatum & 8.2 & 83.3 \\
\hline Diosaccus tenuicornis & 5.6 & 70.8 & Diosaccus tenuicornis & 4.7 & 87.7 \\
\hline \multicolumn{6}{|c|}{ Across factor Site (PERMANOVA: $P<0.014$ ) } \\
\hline \multicolumn{3}{|c|}{ Oscelluccia (OSCE, 69.7\% similarity) } & \multicolumn{3}{|c|}{ Harbour (PORT, 67.5\% similarity) } \\
\hline Species & $\%$ & cum. \% & Species & $\%$ & cum. \% \\
\hline Tisbe furcata & 24.6 & 24.6 & Tisbe furcata & 27.6 & 27.6 \\
\hline Tisbe ensifer & 14.5 & 39.2 & Ectinosoma cf. dentatum & 12.4 & 40.0 \\
\hline Ectinosoma cf. dentatum & 11.0 & 50.2 & Ameira longipes & 11.3 & 51.3 \\
\hline Ameira longipes & 8.9 & 59.1 & Amphiascus minutus & 7.0 & 58.3 \\
\hline Dactylopusia tisboides & 5.2 & 64.3 & Tisbe ensifer & 6.7 & 65.0 \\
\hline
\end{tabular}

The most abundant species in the macrophytodetritus accumulations were also commonly found in adjacent habitats (Hicks and Coull, 1983; Mascart et al., 2013; Novak, 1982). Colonisation by invertebrates is rapid, however, it is limited in its extent and magnitude (Norkko and Bonsdorff, 1996; Palmer, 1988). For that reason active migration or passive dispersion towards macrophytodetritus accumulations was not sufficient to explain comparable quantities and diversities. Dimech et al. (2006) suggested that small accumulations that persisted during the year in depressions of the seabed, harboured some fauna living permanently in this detritus. This implies that some harpacticoid species (morphologically specialised to a certain habitat) also live permanently in macrophytodetritus accumulations.

\subsection{Environmental factors}

The macrophytodetritus showed the highest accumulations and leaf litter dry weights in October, which coincided with the annual leaf fall, starting in September (Bay, 1984). The peak could be explained by the annual senescence, though other factors presumably play a role in the variation of the litter amount during the rest of the year. Enhanced hydrodynamics and storms had been put forward to explain the rise in accumulations of dislodged seagrasses and drift algae. The accumulation of dislodged material was shown to enhance habitat function by increasing structural complexity and food availability (Kirkman and Kendrick, 1997; Lenanton et al., 1982; Ólafsson et al., 2013). However, during higher hydrodynamic periods, the relative contribution of drift macroalgae and living P. oceanica was low. Subsequently, the meiofauna community assemblage was not directly influenced by dislodged material (drift macroalgae and living P. oceanica) in the macrophytodetritus accumulation. However, drift macroalgae were a tertiary explanatory variable for the harpacticoid assemblage and a primary variable for the most abundant harpacticoid species, $T$. ensifer and $A$. longipes. This result, points at a possible species-specific effect regarding the presence of drift macroalgae and its associated micro-epiphytes.

The BEST analysis revealed the median wind gusts as the best explanatory variable for the meiofauna and harpacticoid assemblages in the macrophytodetritus accumulations. Dauby et al. (1995) conducted a sediment trap experiment in the Bay of Calvi that showed that Northerly winds peak from October to April, with maximum values from mid-January to early March, which would cause a bigger disturbance during those months. Vetter (1995) reported low diversities of macro-invertebrates in disturbed leaf litter patches and attributed it to the disturbance by currents. Hovel et al. (2002) stated that hydrodynamic differences between seasons and years could explain the variability in crustacean density by directly influencing larval settlement, feeding rates and/or locomotion of crustaceans. Nonetheless, the yearlong presence of planktonic adults and juveniles in macrophytodetritus accumulations could highlight species-specific adaptations. It is known that copepods have an ability to swim and to emerge from the bottom into the water column and back (Guidi-Guilvard et al., 2009; Teasdale et al., 2004). As a possible consequence some planktonic species could adapt to an epibenthic life (Giere, 2009; Huys et al., 1992). Although in general the orders Calanoida, Cyclopoida and Syphonostomatoida have a planktonic life cycle, feeding on suspended fine-particulate organic matter or they are parasitic on fish and invertebrates (Boxshall and Hasley, 2004). Since, Thistle (2003) concluded that high hydrodynamic flows suppressed emergence, it was thus highly probable that the nonharpacticoid adults and juveniles actively sought shelter in the macrophytodetritus from extensive hydrodynamic movements and predation. Consequently, we could conclude that benthic meiofauna and harpacticoid assemblages were negatively correlated with the wind gust induced water movements. Subsequently, planktonic copepods were to a lesser extent affected by the hydrodynamics, but sought shelter or adapted partially to the macrophytodetritus accumulations.

According to the accumulation and compaction of the detritus, a difference in oxygen penetration depth in the detritus accumulation could be expected. An oxygen gradient from the oxic water column and top layer of the detritus to the hypoxic bottom layer was present and directly influenced the vertical distribution and diversity of the meiobenthos (Higgins and Thiel, 1988). Highly active fauna, especially crustaceans who are usually highly sensitive to hypoxia will be impacted first (Tietjen, 1969). Since harpacticoid copepods are the most sensitive taxon to decreased oxygen (Moodley et al., 2000), they are typically limited to the top layer of the detritus package. Nematodes conversely are more tolerant to low oxygen levels (Murrell and Fleeger, 1989; Wetzel et al., 2001). The Copepoda/Nematoda ratio peaked in August, while the nematode abundance remained fairly constant through the year. This sudden rise in copepod abundances and diversity (especially in the harbour) coincided with the calmest wind period and lowest accumulation height and leaf litter dry weight. Thus we might expect a

Table 5

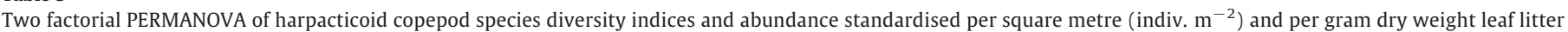
(indiv. $\mathrm{g}^{-1} \mathrm{DW}$ ). $\mathrm{S}=$ species richness, $\mathrm{N} 1$ and $\mathrm{N} 2=$ heterogeneity of diversity.

\begin{tabular}{|c|c|c|c|c|c|}
\hline Factors and interaction & $\mathrm{S}$ & $\mathrm{N}_{1}$ & $\mathrm{~N}_{2}$ & Harpacticoida indiv. $\mathrm{m}^{-2}$ & Harpacticoida indiv. $\mathrm{g}^{-1} \mathrm{DW}$ \\
\hline Month & $F_{(3,16)}^{\prime}=26.0 P<0.001^{* * *}$ & $F_{(3,16)}^{\prime}=5.7 P=0.012^{*}$ & $F_{(3,16)}^{\prime}=4.4 P=0.016^{*}$ & $F_{(3,16)}^{\prime}=4.3 P=0.006^{* *}$ & $F_{(3,16)}^{\prime}=15.1 P<0.001^{* * *}$ \\
\hline Site & $F_{(1,16)}^{\prime}=4.9 P=0.044^{*}$ & $F_{(1,16)}^{\prime}=3.0 P=0.095$ & $F_{(1,16)}^{\prime}=2.3 P=0.156$ & $F_{(1,16)}^{\prime}=1.3 P=0.271$ & $F_{(1,16)}^{\prime}=2.1 P=0.106$ \\
\hline Month $\times$ site & $F_{(3,16)}^{\prime}=4.7 P=0.019^{*}$ & $F_{(3,16)}^{\prime}=1.9 P=0.169$ & $F_{(3,16)}^{\prime}=1.1 P=0.411$ & $F^{\prime}(3,16)=2.0 P=0.099$ & $F_{(3,16)}^{\prime}=6.5 P<0.001^{* * *}$ \\
\hline
\end{tabular}

$*=0.05<P<0.01=$ significant.

$* *=0.01<P<0.001=$ highly significant.

$* * *=P<0.001=$ very highly significant. 
trade-off between harpacticoid copepods and nematode densities according to the oxygen levels present in the accumulation. In our study, no such correlation of oxygen level with the Copepoda/Nematoda ratio was found. This could indicate the patchiness of the oxygen distribution within the accumulation and the high mobility of copepods that could migrate vertically out of the accumulation towards the oxygenrich water just above the detritus. It could furthermore indicate a species-specific behaviour of harpacticoids, like Diosaccus tenuicornis, which was the only dominant harpacticoid species influenced by the oxygen levels. Hence, no overall effect of oxygen concentrations on higher taxa was present, except for the Amphipoda. These abundances negatively correlated to the oxygen levels inside the macrophytodetritus. A possible explanation could be the species-specific behaviour of amphipods towards hypoxia (Gamenick et al., 1996). Another factor to be taken into account is that adults belong to the macrofauna and thus the organisms found are juveniles. These juveniles could possess physiological characteristics which allow them to use the hypoxic accumulation to shelter temporarily from predators that are not adapted to hypoxia.

Next to oxygen, other physico-chemical aspects were altered inside the macrophytodetritus accumulation. Meiofauna are not known to directly assimilate dissolved nutrients (Mitwally and Fleeger, 2013; Siebers, 1982), but physico-chemical fluctuations influence their potential food sources (Atilla et al., 2005; Hall and Bell, 1988; Hicks, 1977, 1980). Therefore, nutrient fluctuations would also presumably impact meiofauna indirectly by altering the habitat structure (Arroyo et al., 2013).

The present seasonal study demonstrated that meiofauna and harpacticoid copepod assemblages in macrophytodetritus accumulations reflect a seasonal cycle with a maximum abundance and diversity during spring-summer and a minimum during winter, coinciding with the epiphytic primary production cycle. These results are congruent with Hall and Bell (1988) and Johnson and Scheibling (1987) who showed that dominant motile invertebrates' abundances and diversities are positively correlated with the habitat complexity as measured by the biomass of seagrass epiphytic algae. As pointed out by several authors, e.g. Wieser (1959), Novak (1982) and Hicks and Coull (1983), abundances and diversity of meiofauna of marine vegetation are positively correlated with habitat complexity and negatively correlated with water movements, which is confirmed by this study.

\section{Conclusions}

Meiofauna was ubiquitously present in the macrophytodetritus accumulations and half is composed of the crustacean subclass Copepoda, of which $87 \%$ belonged to the order Harpacticoida. As a consequence of the harpacticoid copepod species-specific selective feeding, a wide variety of morphologically similar and ecologically different species was present. The macrophytodetritus played an important role in sheltering, housing and feeding possibilities for meiofauna and harpacticoid copepods. These communities' seasonal abundances follow the epiphytic primary production cycle. They were positively correlated with habitat complexity and negatively correlated with water movements and leaf litter accumulations. Migration and dispersion from other adjacent habitats seemed to promote faunal communities, however, a permanent population in the macrophytodetritus accumulations should not be excluded.

Three specific questions in this study were addressed and answered as follows: (1) The macrophytodetritus accumulation and associated communities were mainly determined by seasonal wind induced hydrodynamics and leaf litter biomass. (2) Meiofauna and harpacticoid copepod assemblages displayed a maximum abundance and diversity during May-August (site depending) and a minimum during February. (3) Several ecological groups of copepods, including planktonic, parasitic, mesopsammic, phytal and phytal-swimmer copepods were present

\section{Acknowledgements}

The authors thank the two anonymous referees for their constructive remarks that contributed to the improvement of the manuscript. The authors warmly thank K. Boyle for his native speaker corrections and advice. The authors kindly thank the Stareso field station staff for their assistance during the several sampling campaigns. The authors thank Y. Cornet and J-M. Beckers for the meteorological data exploration and the ocean surface mixed layer model comments, respectively. The first author acknowledges a PhD F.R.I.A. grant (Fund for Research Training in Industry and in Agriculture) of the Belgian National Fund for Scientific Research (FRS-FNRS). This study was conducted within the frame of the FRS-FNRS research project FRFC 2.4511.09 (University of Liège) with additional support provided by the Ghent University (BOF-GOA 01GZ0705 and 01GA1911W). G. Lepoint is a Research Associate of the FRS-FNRS. M. De Troch is a postdoctoral fellow financed by the Special Research Fund of the Ghent University (BOF-GOA 01GA1911W). This is the MARE paper number 274.

\section{References}

Abada Guerroui, H., Willise, A., 1984. Resultats préliminaires de l'étude des constituants chimiques et faunistiques d'une matte d'herbier a Posidonia oceanica, à Fos et sur la Côte Bleue (Bouches-Du-Rhone, France). GIS Posidonie Publications, Marseille.

Anderson, M.J., Gorley, R.N.,Clarke, K.R., 2008. PERMANOVA + for PRIMER: Guide to Software and Statistical Methods. PRIMER-E, Plymouth.

Arroyo, N.L.,Castejon, I.,Dominguez, M.,Terrados, J., 2013. Harpacticoid copepod response to epiphyte load variations in Posidonia oceanica (L.) Delile meadows. Mar. Ecol. 34, 345-362.

Atilla, N.,Fleeger, J.W.,Finelli, C.M., 2005. Effects of habitat complexity and hydrodynamics on the abundance and diversity of small invertebrates colonizing artificial substrates. J. Mar. Res. 63, 1151-1172.

Bay, D., 1984. A field study of the growth dynamics and productivity of Posidonia oceanica (L.) Delile in Calvi Bay, Corsica. Aquat. Bot. 20, 43-64.

Bell, S.S., Walters, K., Hall, M.O., 1987. Habitat utilization by harpacticoid copepods - a morphometric approach. Mar. Ecol. Prog. Ser. 35, 59-64.

Borg, J.A., Rowden, A.A.,Attrill, M.J.,Schembri, P.J.Jones, M.B., 2006. Wanted dead or alive: high diversity of macroinvertebrates associated with living and 'dead' Posidonia oceanica matte. Mar. Biol. 149, 667-677.

Bostrom, C., Bonsdorff, E., 1997. Community structure and spatial variation of benthic invertebrates associated with Zostera marina (L) beds in the northern Baltic Sea. J. Sea Res. 37, 153-166.

Boxshall, G.A., Hasley, S.H., 2004. An Introduction to Copepod Diversity. The Ray Society, London.

Buffan-Dubau, E., Carman, K.R., 2000. Diel feeding behavior of meiofauna and their relationships with microalgal resources. Limnol. Oceanogr. 45, 381-395.

Carman, K.R., Thistle, D., 1985. Microbial food partitioning by three species of benthic copepods. Mar. Biol. 88, 143-148.

Cebrian, J.,Duarte, C.M.,Marba, N.,Enriquez, S., 1997. Magnitude and fate of the production of four co-occurring western Mediterranean seagrass species (vol 155, pg 29, 1997) Mar. Ecol. Prog. Ser. 159, 308

Clarke, K.R., Gorley, R.N., 2006. PRIMER v6. In: PRIMER-E (Ed.), User Manual/Tutorial Plymouth.

Colangelo, M.A., Macrí, T., Ceccherelli, V.U., 1996. A field experiment on the effect of two types of sediment disturbance on the rate of recovery of a meiobenthic community in a eutrophicated lagoon. Hydrobiologia 329, 57-67.

Como, S., Magni, P.,Baroli, M., Casu, D., De Falco, G.,Floris, A., 2008. Comparative analysis of macrofaunal species richness and composition in Posidonia oceanica, Cymodocea nodosa and leaf litter beds. Mar. Biol. 153, 1087-1101.

Connolly, R.M., 1997. Differences in composition of small, motile invertebrate assemblages from seagrass and unvegetated habitats in a southern Australian estuary. Hydrobiologia 346, 137-148.

Coull, B.C., Wells, J.B.J., 1983. Refuges from fish predation - experiments with phytal meiofauna from the New-Zealand rocky intertidals. Ecology 64, 1599-1609.

Cushman-Roisin, B., Beckers, J.M., 2011. Introduction to Geophysical Fluid Dynamics: Physical and Numerical Aspects. Academic Press.

Danovaro, R., 1996. Detritus-bacteria-meiofauna interactions in a seagrass bed (Posidonia oceanica) of the NW Mediterranean. Mar. Biol. 127, 1-13.

Danovaro, R., Gambi, C., Mirto, S., 2002. Meiofaunal production and energy transfer efficiency in a seagrass Posidonia oceanica bed in the western Mediterranean. Mar. Ecol. Prog. Ser. 234, 95-104.

Dauby, P., Poulicek, M., 1995. Methods for removing epiphytes from seagrasses: SEM observations on treated leaves. Aquat. Bot. 52, 217-228.

Dauby, P., Bale, A.J., Bloomer, N., Canon, C., Ling, R.D., Norro, A., Robertson, J.E., Simon, A., Théate, J.M.,Watson, A.J.,Frankignoulle, M., 1995. Particle fluxes over a Mediterranean seagrass bed: a one year case study. Mar. Ecol. Prog. Ser. 126, 233-246.

De Troch, M., Fiers, F., Vincx, M., 2001. Alpha and beta diversity of harpacticoid copepods in a tropical seagrass bed: the relation between diversity and species' range size distribution. Mar. Ecol. Prog. Ser. 215, 225-236. 
De Troch, M., Melgo-Ebarle, J.L., Angsinco-Jimenez, L., Gheerardyn, H.,Vincx, M., 2008. Diversity and habitat selectivity of harpacticoid copepods from sea grass beds in Pujada Bay, the Philippines. J. Mar. Biol. Assoc. U. K. 88, 515-526.

De Troch, M., Vergaerde, I., Cnudde, C., Vanormelingen, P., Vyverman, W., Vincx, M., 2012 The taste of diatoms: the role of diatom growth phase characteristics and associated bacteria for benthic copepod grazing. Aquat. Microb. Ecol. 67, 47-58.

Decho, A.W., Castenholz, R.W., 1986. Spatial patterns and feeding of meiobenthic harpacticoid copepods in relation to resident microbial flora. Hydrobiologia 131, 87-96.

Dimech, M., Borg, J.A., Schembri, P.J., 2006. Motile macroinvertebrate assemblages associated with submerged posidonia oceanica litter accumulations. Biol. Mar. Mediterr. 13 130-133.

Duarte, C.M., Cebrian, J., 1996. The fate of marine autotrophic production. Limnol Oceanogr. 41, 1758-1766.

Dumont, H.J., Maas, S., 1988. Five new species of leaf litter harpacticoids (Crustacea, Copepoda) from Nepal. Zool. Scr. 17, 55-68.

Edgar, G.J., Shaw, C., Watson, G.F., Hammond, L.S., 1994. Comparisons of species richness, size-structure and production of benthos in vegetated and unvegetated habitats in Western Port, Victoria. J. Exp. Mar. Biol. Ecol. 176, 201-226.

Enriquez, S., Duarte, C.M., Sandjensen, K., 1993. Patterns in decomposition rates among photosynthetic organisms - the importance of detritus C-N-P content. Oecologia $94,457-471$.

Fiers, F.,Ghenne, V., 2000. Cryptozoic copepods from Belgium: diversity and biogeographic implications. Belg. J. Zool. 130, 11-19.

Fonseca, G., Hutchings, P., Gallucci, F., 2011. Meiobenthic communities of seagrass beds (Zostera capricorni) and unvegetated sediments along the coast of New South Wales, Australia. Estuar. Coast. Shelf Sci. 91, 69-77.

Gallmetzer, I., Pflugfelder, B.,Zekely, J., Ott, J.A., 2005. Macrofauna diversity in Posidonia oceanica detritus: distribution and diversity of mobile macrofauna in shallow sublittoral accumulations of Posidonia oceanica detritus. Mar. Biol. 147, 517-523.

Gamenick, I.,Jahn, A.,Vopel, K., Giere, O., 1996. Hypoxia and sulphide as structuring factors in a macrozoobenthic community on the Baltic Sea shore: colonisation studies and tolerance experiments. Mar. Ecol. Prog. Ser. 144, 73-85.

Gee, J.M., Somerfield, P.J., 1997. Do mangrove diversity and leaf litter decay promote meiofaunal diversity? J. Exp. Mar. Biol. Ecol. 218, 13-33.

Giere, O., 2009. Meiobenthology - The Microscopic Motile Fauna of Aquatic Sediments, Second ed. Springer, Berlin.

Gobert, S.,Lepoint, G., Biondo, R., Bouquegneau, J.M., 2006. In situ sampling of pore waters from seagrass meadows. In: Mediterrenea, B.M. (Ed.), Proceedings of the Mediterranean Seagrass Workshop, Malta, pp. 230-234.

Graca, M.A.S., 2001. The role of invertebrates on leaf litter decomposition in streams review. Int. Rev. Hydrobiol. 86, 383-393.

Grasshoff, K., Kremling, K., Ehrhardt, M., 2007. Methods of Seawater Analysis, Third ed. Wiley-VCH Verlag GmbH.

Guidi-Guilvard, L.D., Thistle, D., Khripounoff, A., Gasparini, S., 2009. Dynamics of benthic copepods and other meiofauna in the benthic boundary layer of the deep NW Mediterranean Sea. Mar. Ecol. Prog. Ser. 396, 181-195.

Gwyther, J., 2003. Nematode assemblages from Avicennia marina leaf litter in a temperate mangrove forest in south-eastern Australia. Mar. Biol. 142, 289-297.

Hall, M.O., Bell, S.S., 1988. Response of small motile epifauna to complexity of epiphytic algae on seagrass blades. J. Mar. Res. 46, 613-630.

Harmelin, J.G., 1964. Etude de l'endofaune des "mattes" d'herbiers de Posidonia oceanica Delile, Recueil des Travaux de la Station Marine d'Endoume-Marseille. Université d'Aix-Marseille, Marseille, pp. 43-105.

Harrison, P.G., Mann, K.H., 1975. Detritus formation from eelgrass (Zostera marina L.) relative effects of fragmentation, leaching and decay. Limnol. Oceanogr. 20, 924-934.

Heip, C., Willems, K., Van hauwermeiren, G., 1983. Een systematisch-ecologische studie van Copepoda harpacticoida levend op bruinwieren van het genus Cystoseira in de Baai van Calvi (Corsica). LUC, Diepenbeek.

Hicks, G.R.F., 1977. Observations on substrate preference of marine phytal harpacticoids (copepoda). Hydrobiologia 56, 7-9.

Hicks, G.R.F., 1980. Structure of phytal harpacticoid copepod assemblages and the influence of habitat complexity and turbidity. J. Exp. Mar. Biol. Ecol. 44, 157-192.

Hicks, G.R.F.,Coull, B.C., 1983. The ecology of marine meiobenthic harpacticoid copepods. Oceanogr. Mar. Biol. 21, 67-175.

Higgins, R., Thiel, H., 1988. Introduction to the Study of Meiofauna. Smithsonian Institution Press, London.

Hill, M.O., 1973. Diversity and eveness - unifying notation and its consequences. Ecology 54, 427-432.

Hovel, K.A., Fonseca, M.S., Myer, D.L., Kenworthy, W.J., Whitfield, P.E., 2002. Effects of seagrass landscape structure, structural complexity and hydrodynamic regime on macrofaunal densities in North Carolina seagrass beds. Mar. Ecol. Prog. Ser. 243 $11-24$.

Hulings, N.C., Gray, J.S., 1971. A manual for the study of meiofauna. Smithson. Contrib. Zool. 78, 1-83.

Huys, R.,Herman, P.M.J.,Heip, C.H.R.,Soetaert, K., 1992. The meiobenthos of the North Sea: density, biomass trends and distribution of copepod communities. ICES J. Mar. Sci. 49, $23-44$

Hyndes, G.A., Lavery, P.S., 2005. Does transported seagrass provide an important trophic link in unvegetated, nearshore areas? Estuar. Coast. Shelf Sci. 63, 633-643.

Johnson, S.C., Scheibling, R.E., 1987. Structure and dynamics of epifaunal assemblages on intertidal macroalgae Ascophyllum nodosum and Fucus vesiculosus in Nova Scotia, Canada. Mar. Ecol. Prog. Ser. 37, 209-227.

Kirkman, H., Kendrick, G.A., 1997. Ecological significance and commercial harvesting of drifting and beach-cast macro-algae and seagrasses in Australia: a review. J. Appl. Phycol. 9, 311-326.
Lang, K., 1948. Monographie der Harpacticiden. Hâkan Ohlssons boktryckeri, Lund.

Lang, K., 1965. Copepoda Harpacticoidea from the Californian Pacific Coast.

Lee, J., Tietjen, J., Mastropaolo, C., Rubin, H., 1977. Food quality and the heterogeneous spatial distribution of meiofauna. Helgol. Mar. Res. 30, 272-282.

Lenanton, R.C.J., Robertson, A.I., Hansen, J.A., 1982. Nearshore accumulations of detached macrophytes as nursery areas for fish. Mar. Ecol. Prog. Ser. 9, 51-57.

Lepoint, G., Nyssen, F., Gobert, S., Dauby, P., Bouquegneau, J.M., 2000. Relative impact of a seagrass bed and its adjacent epilithic algal community in consumer diets. Mar. Biol. 136, 513-518.

Lepoint, G., Cox, A.S., Dauby, P., Poulicek, M., Gobert, S., 2006. Food sources of two detritivore amphipods associated with the seagrass Posidonia oceanica leaf litter. Mar. Biol. Res. 2, 355-365.

Lillebo, A.I., Flindt, M.R., Pardal, M.A., Cardoso, P.G., Ferreira, S.M., Marques, J.C., 2007. The faunal role in the degradation of the common intertidal salt marsh plant Scirpus maritimus. Hydrobiologia 579, 369-378.

Mancinelli, G., Rossi, L., 2002. The influence of allochthonous leaf detritus on the occurrence of crustacean detritivores in the soft-bottom macrobenthos of the Po River Delta area (northwestern Adriatic Sea). Estuar. Coast. Shelf Sci. 54, 849-861.

Mascart, T.,Lepoint, G.,De Troch, M., 2013. Meiofauna and harpacticoid copepods in different habitats of a Mediterranean seagrass meadow. J. Mar. Biol. Assoc. U. K. 93, 1557-1566.

Mateo, M.A., Romero, J., 1997. Detritus dynamics in the seagrass Posidonia oceanica: elements for an ecosystem carbon and nutrient budget. Mar. Ecol. Prog. Ser. 151, 43-53.

Meyer, H.A., Bell, S.S., 1989. Response of Harpacticoid copepods to detrital accumulation on seagrass blades - a field experiment with Metis holothuriae (Edwards). J. Exp. Mar. Biol. Ecol. 132, 141-149.

Middelburg, J.J.,Levin, L.A., 2009. Coastal hypoxia and sediment biogeochemistry. Biogeosciences 6, 1273-1293.

Mitwally, H., Fleeger, J., 2013. Long-term nutrient enrichment elicits a weak density response by saltmarsh meiofauna. Hydrobiologia 713, 97-114.

Moodley, L., Chen, G.T.,Heip, C.,Vincx, M., 2000. Vertical distribution of meiofauna in sediments from contrasting sites in the Adriatic Sea: clues to the role of abiotic versus biotic control. Ophelia 53, 203-212.

Murrell, M.C.,Fleeger, J.W., 1989. Meiofauna abundance on the Gulf of Mexico continental shelf affected by hypoxia. Cont. Shelf Res. 9, 1049-1062.

Norkko, A., Bonsdorff, E., 1996. Rapid zoobenthic community responses to accumulations of drifting algae. Mar. Ecol. Prog. Ser. 131, 143-157.

Novak, R., 1982. Spatial and seasonal distribution of the meiofauna in the seagrass Posidonia oceanica. Neth. J. Sea Res. 16, 380-388.

Ólafsson, E.,Aarnio, K., Bonsdorff, E.,Arroyo, N.L., 2013. Fauna of the green alga Cladophora glomerata in the Baltic Sea: density, diversity, and algal decomposition stage. Mar. Biol. 160, 2353-2362.

Pace, M.C., Carman, K.R., 1996. Interspecific differences among meiobenthic copepods in the use of microalgal food resources. Mar. Ecol. Prog. Ser. 143, 77-86.

Palmer, M.A., 1988. Dispersal of marine meiofauna a review and conceptual model explaining passive transport and active emergence with implications for recruitment. Mar. Ecol. Prog. Ser. 48, 81-91.

Pergent, G., Romero, J., Pergentmartini, C., Mateo, M.A., Boudouresque, C.F., 1994. Primary production, stocks and fluxes in the Mediterranean seagrass Posidonia oceanica. Mar. Ecol. Prog. Ser. 106, 139-146.

Pergent, G., Rico-Raimondino, V., Pergent-Martini, C., 1997. Fate of primary production in Posidonia oceanica meadows of the Mediterranean. Aquat. Bot. 59, 307-321.

Pergent-Martini, C., Rico-Raimondino, V., Pergent, G., 1994. Primary production of Posidonia oceanica in the Mediterranean Basin. Mar. Biol. 120, 9-15.

Quinn, G.G.P., Keough, M.J., 2002. Experimental Design and Data Analysis for Biologists. Cambridge University Press.

Romero, J., Perez, M., Mateo, M.A.,Sala, E., 1994. The belowground organs of the Mediterranean seagrass Posidonia oceanica as a biogeochemical sink. Aquat. Bot. 47, 13-19.

Sanchez-Jerez, P., Cebrian, C.B., Espla, A.A.R., 1999. Comparison of the epifauna spatial distribution in Posidonia oceanica, Cymodocea nodosa and unvegetated bottoms: importance of meadow edges. Acta Oecol. Int. J. Ecol. 20, 391-405.

Siebers, D., 1982. Bacterial-invertebrate interactions in uptake of dissolved organic matter. Am. Zool. 22, 723-733.

Steinarsdóttir, M.B.,Ingólfsson, A Ólafsson, E. 2003. Seasonality of harpacticoids (Crustacea, Copepoda) in a tidal pool in subarctic south-western Iceland. Hydrobiologia 503, 211-221

Strickland, J.D.H., Parsons, T.R., 1968. Determination of dissolved oxygen, In: Stevenson, J. C. (Ed.), A Practical Handbook of Seawater Analysis, Second ed.Fisheries research board of Canada, Ottawa, pp. 71-75.

Teasdale, M.,Vopel, K., Thistle, D., 2004. The timing of benthic copepod emergence. Limnol. Oceanogr. 49, 884-889.

Thistle, D., 2003. Harpacticoid copepod emergence at a shelf site in summer and winter: implications for hydrodynamic and mating hypotheses. Mar. Ecol. Prog. Ser. 248, $177-185$.

Tietjen, J., 1969. The ecology of shallow water meiofauna in two New England estuaries. Oecologia 2, 251-291.

Torres-Pratts, H.,Schizas, N.V., 2007. Meiofaunal colonization of decaying leaves of the red mangrove Rhizophora mangle, in Southwestern Puerto Rico. Caribb. J. Sci. 43, 127-137.

Ustach, J.F., 1982. Algae, bacteria and detritus as food for harpacticoid copepod, Heteropsyllus pseudonunni Coull and Palmer. J. Exp. Mar. Biol. Ecol. 64, 203-214.

Vetter, E.W., 1995. Detritus-based patches of high secondary production in the nearshore benthos. Mar. Ecol. Prog. Ser. 120, 251-262.

Vetter, E.W., Dayton, P.K., 1999. Organic enrichment by macrophyte detritus, and abundance patterns of megafaunal populations in submarine canyons. Mar. Ecol. Prog. Ser. 186, 137-148. 
Walters, K., 1991. Influences of abundance, behavior, species composition, and ontogenetic stage on active emergence of meiobenthic copepods in subtropical habitats. Mar. Biol. 108, 207-215.

Wetzel, M.A.,Fleeger, J.W.,Powers, S.P., 2001. Effects of hypoxia and anoxia on meiofauna: a review with new data from the Gulf of Mexico. In: Rabalais, N.N. (Ed.), Coastal Hypoxia: Consequences for Living Resources and Ecosystems. Coastal and Estuarine Sciences, vol. 58, pp. 165-184.

Wieser, W., 1959. Zur Ökologie der Fauna Mariner Algen Mit Besonderer Berücksichtigung Des Mittelmeeres. Int. Rev. Ges. Hydrobiol. Hydrogr. 44, 137-179.
Wittman, K.,Scipione, M.B.,Fresi, E., 1981. Some laboratory experiments on the activity of the macrofauna in the fragmentation of detrital leaves of Posidonia oceanica (L.) Delile. Rapports et Procès-Verbaux des Réunions de la Commission Internationale pour l'Exploration Scientifique de la Mer Méditerranée. , 27, pp. 205-206.

Wyckmans, M.,Chepurnov, V.A.,Vanreusel, A.,De Troch, M., 2007. Effects of food diversity on diatom selection by harpacticoid copepods. J. Exp. Mar. Biol. Ecol. 345, 119-128. 